IZADP No. 2582

The Changing Nature of the School-to-Work Transition Process in OECD Countries

\author{
Glenda Quintini \\ J ohn P. Martin \\ Sébastien Martin \\ J anuary 2007
}




\title{
The Changing Nature of the School-to-Work Transition Process in OECD Countries
}

\author{
Glenda Quintini \\ $O E C D$ \\ John P. Martin \\ $O E C D$ and IZA \\ Sébastien Martin \\ $O E C D$
}

Discussion Paper No. 2582

January 2007

IZA

P.O. Box 7240

53072 Bonn

Germany

Phone: +49-228-3894-0

Fax: +49-228-3894-180

E-mail: iza@iza.org

\begin{abstract}
Any opinions expressed here are those of the author(s) and not those of the institute. Research disseminated by IZA may include views on policy, but the institute itself takes no institutional policy positions.

The Institute for the Study of Labor (IZA) in Bonn is a local and virtual international research center and a place of communication between science, politics and business. IZA is an independent nonprofit company supported by Deutsche Post World Net. The center is associated with the University of Bonn and offers a stimulating research environment through its research networks, research support, and visitors and doctoral programs. IZA engages in (i) original and internationally competitive research in all fields of labor economics, (ii) development of policy concepts, and (iii) dissemination of research results and concepts to the interested public.
\end{abstract}

IZA Discussion Papers often represent preliminary work and are circulated to encourage discussion. Citation of such a paper should account for its provisional character. A revised version may be available directly from the author. 


\section{ABSTRACT \\ The Changing Nature of the School-to-Work Transition Process in OECD Countries}

Despite the fact that today's young cohorts are smaller in number and better educated than their older counterparts, high youth unemployment remains a serious problem in many OECD countries. This reflects a variety of factors, including the relatively high proportion of young people leaving school without a basic education qualification, the fact that skills acquired in initial education are not always well adapted to labour market requirements, as well as general labour market conditions and problems in the functioning of labour markets. The paper highlights the contrasting trends in youth labour market performance over the past decade using a wide range of indicators. It also presents new evidence on i) the length of transitions from school to work; and ii) the degree to which temporary jobs serve as either traps for young people or stepping-stones to good careers. In addition, the paper reviews some recent policy innovations to improve youth employment prospects.

JEL Classification: $\quad$ J13, J21, J24

Keywords: $\quad$ youth labour market, school-to-work transition, temporary and permanent contracts, apprenticeship, youth labour market programmes

Corresponding author:

John P. Martin

OECD

Directorate for Employment, Labour and Social Affairs

2 , rue André Pascal

F-75775 Paris Cedex 16

France

E-mail: John.Martin@oecd.org

\footnotetext{
* The paper was presented at the Conference on the European Social Model "Joining forces for a social Europe", 8-9 February 2007, Nuremberg. It is an abridged and lightly revised version of a recently published OECD Working Paper by Glenda Quintini and Sébastien Martin, "Starting Well or Losing their Way? The Position of Youth in the Labour Market in OECD Countries", OECD Social, Employment and Migration Working Paper No. 39, see http://www.OECD.ORG/ELS/workingpapers. The views expressed here are our own and cannot be held to be those of the OECD or of its member countries.
} 


\section{THE CHANGING NATURE OF THE SCHOOL-TO-WORK TRANSITION PROCESS IN OECD COUNTRIES}

\section{Introduction}

1. There is growing concern regarding the situation of youth in the labour market. Despite the fact that today's young cohorts are smaller in number and better educated than their older counterparts, high youth unemployment remains a serious problem in many OECD countries. In addition, it is sometimes claimed that job instability has tended to increase among those youths that do have a job.

2. The main purpose of this paper is to examine how OECD countries compare with respect to school-to-work transitions and analyse the extent to which the situation of youth in the labour market has changed over the past decade or so -unless mentioned otherwise, for the purposes of this report, the terms "youth", "teenagers" and "young adults" refer to the age-groups 15/16-24, 15/16-19 and 20-24, respectively. In addition, the paper highlights some recent policy innovations to improve youth employment prospects.

3. The paper is organised as follows. Section 1 presents a scoreboard of the position of youth in the labour market using a battery of statistical indicators, paying particular attention to trends over the past decade. Section 2 highlights several major policies which aim to combat youth labour market problems, paying particular attention to recent findings. The final section draws some conclusions.

\section{Youth labour market performance over the past decade: a statistical scoreboard}

\subsection{A picture of the difficulties faced by youth: unemployment and joblessness}

4. This section paints the position of youth in the labour market and how it has changed over the past decade. The conventional indicators of labour market performance - unemployment and employment rates - can paint a misleading picture when applied to the youth labour market. This is because many young people tend to combine schooling with part-time work and/or job search; they often intersperse spells of inactivity with spells of work or job search; and the process of settling into the labour market is often prolonged and discontinuous rather than a smooth and quick transition. For these reasons, this part of the paper supplements the conventional indicators of labour market performance with a range of other indicators of youth labour market performance such as the proportion of youth neither in employment nor in education and the incidence of low-paid jobs among youth. It also looks at the types of jobs held by young people during the transition process and seeks to establish the extent to which these jobs serve as socalled "traps" or stepping-stones.

\section{Standard measures of labour market performance: unemployment and employment rates}

5. In 2005, 15.7\% of youth participating in the labour market were unemployed on average in OECD countries (Figure 1, Panel A), down from 16.4\% ten years earlier. Youth unemployment rates fell in several countries, including many of those where they were very high in 1995 - notably, Finland, Ireland, Italy, and Spain. Among the largest declines, the youth unemployment rate almost halved in Spain over the past decade and a very sharp fall was also recorded in Ireland. 
6. Despite the decline in the OECD average, youth unemployment rates remain very high in about half of the OECD countries, with extremes in Poland and the Slovak Republic - 38\% and 30\%, respectively, in 2005 - and rates exceeding 20\% in France, Greece, Italy and Sweden. At the other end of the spectrum, Mexico - at 6.6\% in 2005 - has the lowest rate of unemployment for young people, followed closely by Iceland, Denmark, and Ireland.

7. Perhaps a more relevant indicator than the youth unemployment rate, which is affected by the business cycle, is the ratio of youth to prime-age (i.e. the 25-54 age group) adult unemployment rates (Figure 1, Panel B). This ratio has risen slightly over the past decade, from 2.4 in 1995 to 2.7 in 2005, with increases recorded in more than two thirds of OECD countries. In 2005, in all 30 OECD countries, youth were more likely to be unemployed than prime-age adults - i.e. the ratio is always larger than one. And in 28 of the 30 OECD countries, the unemployment rate of youth was more than twice that of adults - with Denmark and Germany being the sole exceptions.

Figure 1. Unemployment and Employment rates of youth in OECD countries, 1994-2004

8. Another indicator of youth labour market performance, the employment rate, points to a slight deterioration in youth labour market performance: $42.3 \%$ of all youth were employed, on average, in the OECD in 2005 (Figure 1, Panel C), down from 43.6\% in 1995. Employment rates have fallen over the past decade in several OECD countries - notably in Eastern and Southern Europe, OECD Asia, Mexico and the United States, Austria, Denmark, Germany, Luxembourg, and the United Kingdom. Although in general, a fall in employment rates for young people need not be bad news as it may indicate that they are spending more time in education, many of the countries where a fall was observed experienced a parallel rise in unemployment.

9. Looking at levels in 2005, large cross-country differences can be observed, with employment rates ranging from more than $60 \%$ in Australia, Denmark, Iceland, and the Netherlands, to just over 20\% in Hungary and Poland.

\section{Youth neither in education nor in employment}

10. While the unemployment and employment rates remain useful indicators of youth labour market performance, it is important to remember that youth who face employment difficulties may be inactive instead of unemployed. Indeed, young people are particularly likely to drop out of the labour force and become inactive when jobs are hard to find. At the same time, the increase in the inactivity rate is partly accounted for by the growing share of young people who tend to stay in education beyond the age of compulsory schooling and it would be inappropriate to count these young people as a high-risk group. For this reason, we prefer an indicator of joblessness which accounts for all those who are neither in education nor in employment (NEET), as a more accurate proxy of the size of the group of young people most at risk on the labour market.

Figure 2. Share of teenagers and young adults neither in education nor in employment (2003-1996)

11. This particular indicator suggests a small improvement in performance: on average in 2003, almost $17 \%$ of young adults were neither in education nor in employment in OECD countries, down 2 percentage points since 1996 (see Figure 2). Above-average NEET rates were observed in Eastern European countries, Greece, Italy, Mexico and Turkey, although some of these countries recorded sharp declines since 1996 - this is the case, notably, in Hungary, Poland, Greece and Mexico. The picture for 
teenagers is slightly better, with only about $8 \%$ of them neither in education nor in employment reflecting compulsory education requirements. ${ }^{1}$

12. Obviously, youth who leave school without qualifications are more likely to be neither in education nor in employment than their more educated counterparts (Figure 3). In addition, within this group, rates for women are particularly high - reaching more than $70 \%$ in Eastern European countries, Greece, Mexico and Turkey, and more than 50\% in Germany, Ireland, Italy and New Zealand. As average qualification levels rise, NEET rates tend to decrease and gender differences shrink. Nevertheless, NEET rates remain high at least up to upper secondary education, and for some countries - notably Belgium, Hungary, Italy, New Zealand and Turkey - NEET rates in excess of $10 \%$, on average, across gender, are still observed for individuals with tertiary education qualifications.

13. But the data on NEET rates in Figures 2 and 3 are cross-sectional in nature. It could be argued that a brief spell of NEET status is quite normal for many young people as part of the school-to-work transition rather than an early warning of high labour market risk. While there is some truth in this argument, it is less to easy to accept if the length of time spent in the NEET status is quite long. In order to address this issue, longitudinal data which track the same young people over time are needed. Figure 4 uses such data for the period 1997-2001 from the European Community Household Panel (ECHP) and a similar US survey to shed some light on the persistence of the NEET status for young people. It provides a comparison of the share of youth who are NEET in each single year and two measures of NEET status incidence over five years: the larger share of persons ever-NEET during the five-year period (those who have been NEET at least once) and the smaller share of always-NEET. The ratio of ever NEET to always NEET gives a measure of turnover in NEET status. If there were no turnover in the NEET population, the ever, single-year and always-NEET incidence rates would be equal (see also OECD, 1997).

Figure 3. NEET rates by educational level and gender, 2003

Figure 4. Alternative incidence measures of NEET status of youth, 15-24, 1997-2001

14. Figure 4, Panel A, shows that there is some turnover in the NEET group for those countries for which data are available. In Austria, very few young people are continuously NEET over the five years. And in Finland almost ten times as many young persons were NEET at some point during the five-year period as were continuously NEET during that period, implying considerable movement into and out of the NEET status. ${ }^{2}$ In all countries, turnover in the NEET group is higher for youth (4.3 on average) than for prime-age adults (2.2 on average). However, a hardcore group of youth with NEET status over the entire 5 -year period can be identified in several European countries. The share of youth in the "always NEET" category is rather high in Italy - about 30\% - and in Greece - approximately $20 \%$, and it exceeds $10 \%$ in several other countries, including France, Germany, Ireland, the Netherlands and Spain. In addition, data on the so-called "recurrence rate" in Panel B show that in Finland, the United States and France, more than $15 \%$ of young people who were NEET in 1997 experienced more than one NEET spell over the five following years. And in 9 out of 11 countries represented, youth were likely to spend three or more of the four years out of work and education.

1. It is important to note that even when youth NEET rates are very high, this may be generated by choices (e.g., travel, leisure), or by non-economic constraints (e.g., military conscription). For example, in Sweden, around half the inactivity of young adult males is associated with military service and foreign travel.

2. Note that some of the NEET turnover is due to military service in those countries where it applies. 


\section{Labour market flows and unemployment durations}

15. It has been known for a while that youth tend to experience more frequent but shorter unemployment spells than prime-age or older workers (see Martin et al. (1984); OECD (1983); and Freeman and Wise, 1982). Figure 5 confirms this fact and shows that, in 2005, the incidence of long-term unemployment among the youth unemployed was always less than among the adult unemployed (see Figure 5, in brackets). In about half the countries, most young people were unemployed for less than three months in 2005 - i.e. the median duration of unemployment was shorter than three months. At the same time, in 2005, in half the countries, more than 1 in 5 youth experienced unemployment durations in excess of 52 weeks, suggesting the existence of serious labour market difficulties for a small group of young people.

16. At the same time, this indicator suggests some improvement in the duration of youth unemployment over the past decade: on average the incidence of long-term unemployment among the young unemployed fell from about 25\% in 1995 to around 20\% in 2005. However, some of the countries starting off with a high share of long-term unemployed have seen a further increase, notably Eastern European countries.

Figure 5. Incidence of long-term unemployment among youth

Figure 6. Job hires and job changes, 2004

Figure 7. Job quits and job lossers, 2004

17. Figures 6 and 7 present further information on youth and adult labour market dynamics. Unsurprisingly, youth represent a high proportion of new hires and job changers (Figure 6). Job quits are also more common among them than for adults (Figure 7). Overall, this is consistent with the fact that youth tend to change jobs more frequently at the beginning of their career in search for the best possible match between their skills and those required by employers - so-called job shopping. ${ }^{3}$

\subsection{The length of school-to-work transitions in OECD countries}

18. Evidence for European countries shows that, one year after leaving school, many young people are still without work - more than $50 \%$ in Greece, Poland, Italy, and the Slovak Republic (see Figure 8, Panel A). Even in the best performing European countries (Netherlands and Switzerland), about 20\% of young people did not have a job one year after leaving school. However, the averages presented in Panel A hide important differences across educational qualifications (see Panels B, C, and D). Indeed, while the country ranking remains rather stable, rates of non-employment tend to decrease with educational qualifications. For instance, in Greece, more than $80 \%$ of those without an upper-secondary qualification are non-employed one year after leaving school, while the corresponding rate is approximately $55 \%$ for those with an upper-secondary qualification and $45 \%$ for the most educated. The Netherlands, Switzerland and Denmark are the three best performers at all skill levels.

Figure 8. Labour Market Status one year after leaving school, 2004

19. Figure 9 adds a dynamic dimension to the activity status of youth by looking at shares in each status between the ages of 15 and 29. Obviously, as time passes, the share in education decreases and the

3. Note that high turnover and job shopping by youth are not new phenomena. Indeed, it has always been the case - see OECD (1983) - that high youth unemployment rates are due mainly to high frequency of entry to unemployment rather than relatively long average duration of unemployment spells. To a certain extent, this is just part of the natural dynamics of settling into the world of work. 
share in employment increases. However, it is interesting to see that once the NEET area in the chart reaches its maximum size (between ages 18 and 20), it tends to remain roughly constant for later ages. While Figure 4 above suggests some turnover within youth in the NEET category, these data show that NEET status can be quite persistent in some countries, notably Italy and Greece, and that some young people tend to experience repeated spells out of work and education and these spells have high cumulative durations.

Figure 9. Share of persons aged 15-29 by activity status in Europe, 2002

20. To quantify the average length of transitions from school to work in European countries, Table 1 presents longitudinal data from successive waves of the ECHP over the seven-year period (1994-2000). The data follow individuals from the date they completed their schooling until the first time they report finding a job ${ }^{4}$. The estimates suggest three main findings. First, it often takes quite a long time $-1-2$ years or more - for young people to find their first job after finishing education. Second, there are large differences in the average length of the transition across countries.

21. For example, Spanish, Italian and Finnish school leavers are those that take longest to find a first job, with transitions of more than two years. At the other end of the scale, school leavers in Ireland, Denmark, and Germany take one to one and a half years on average to find their first job. Third, it takes a good bit longer in all cases for young people to find a permanent job (see Table 1, final column). Finding a permanent job ranges from a low of just under two years in Denmark to a high of almost 6 years in Spain. The high degree of labour market segmentation between temporary and permanent jobs in the Southern European countries is reflected in the long wait for young people before they get a permanent contract.

22. The data shown in Table 1 are longitudinal data. It is possible to use cross-section data from the EU Labour Force Survey (EU LFS) to derive an alternative proxy for the average length of time it takes someone leaving education in Europe to find a first job. Here the concept used is the difference between the average age when $50 \%$ of those aged $15-28$ are no longer in education and the average age when $50 \%$ of the same age group are in employment for the year in question. This proxy measure then corresponds to the difference in the median ages of being in education as opposed to having a first job. It has the advantage that it can be estimated over time so that one can assess changes in the average length of the transition over the past decade.

23. The EU LFS estimates are shown in Table 2. There are some similarities but also some notable differences between the longitudinal and cross-section estimates. First, both sets of estimates suggest that it takes a long time for youth in many EU countries to find a first job after leaving education: estimates of two or more years are quite common. Second, the cross-country patterns show some notable differences depending on whether one uses the longitudinal or the cross-section data. For example, the latter point to much longer average lengths to find a first job in Germany and Italy than the ECHP data ${ }^{5}$. At the same

4. The length of transition is calculated only for those who actually found a job over the 7-year period but inclusion of those who had not found a job yet in the year 2000 - to whom a value of 7 years was attributed - hardly changes the results (available on request). The estimates reported here are biased upwards for two reasons. First, they exclude jobs of less than 15 hours per week; apprentices are also excluded. Second, the calculation starts from the calendar date when a young person received the highest education diploma. Thus, it excludes those episodes where a young person combined a job with education. Also note that the number of observations from the ECHP is small so the results must be taken with care. For these reasons, these estimates are only suggestive of differences in the length of transitions from school to work across countries.

5. The rank correlation coefficient between the estimates in Tables 1 and 2 for the 12 countries for which we have common estimates is 0.38 , which is not statistically significant. 
time, the EULFS data suggest that there was a small decline of over 2 months in the average time it took a young person in these 20 EU countries to find a job between 1995 and 2005.

Table 1. Average duration of transitions from school to work in Europe, 1994-2000

Table 2. Expected length of school-to-work transitions in selected OECD countries, 1995, 2000 and 2005

24. In addition, as noted above, the first few years on the labour market after leaving school are usually characterised by high job turnover and multiple spells of unemployment. Table 3 presents information on the number of spells of unemployment experienced by young people over the seven years after leaving school. It shows that, in Germany and Austria - where the apprenticeship system is most developed - more than half of those leaving school find a job without experiencing any unemployment. In Spain, on the other hand, multiple spells are common among youth, with $56 \%$ of them experiencing two or more over the seven years considered. For some of the countries included, Table 3 suggests some polarisation of unemployment experience among recent school leavers, with peaks at no spell or two or more spells and fewer individuals in between - i.e. Belgium, Finland, France, and Portugal. This may reflect differences in behaviour by qualification but the sample is too small to tackle this issue.

Table 3. Unemployment experience of youth out-of-school in Europe, 1994-2000

25. The total time spent in unemployment over the seven reference years is also interesting. In Southern European countries, youth spend on average about one fourth of their time in unemployment, while in Austria, Denmark, and Ireland they only are unemployed about five months out of the 84 .

\subsection{What entry jobs for youth?}

26. As young people enter the labour market for the first time, employers may be reluctant to hire them on permanent contracts or on a full-time basis and entry wages are likely to be lower to account for time spent on training in the first job. In addition, as young people lack previous experience, employers who cannot fully observe their productivity and skills may hire them on jobs that require less than their qualifications. There may even be a link between the availability of temporary, part-time and low-pay jobs for young people and their employment rates. In other words, there could be a trade-off between accepting a job with these characteristics or remaining unemployed much longer. However, while the stepping-stone nature of these jobs would be welcome, temporary work and low-pay traps - i.e. young people unable to move to more stable employment or better paid jobs - could pose a problem. For instance, temporary jobs tend to give fewer training opportunities than permanent contracts and low pay and precariousness may lead young people to delay emancipation from their parents as well as their own family formation.

27. This section looks at two key characteristics of entry jobs: (i) the incidence of temporary and part-time work; and (ii) the incidence of low pay.

Temporary work for young people: a stepping stone or trap?

28. Although temporary jobs already were a dominant feature of youth employment in the mid1990s, the share of youth on temporary jobs has increased further over the past decade (see Figure 10) in most OECD countries, with the exception of Northern European countries, Ireland, Spain and Turkey. In addition, the share of employed youth on temporary jobs continues to be much higher than for adults in OECD countries. Among school leavers who find a job, temporary employment seems to be the rule in Europe. Figure 11 shows that in Spain, 8 in 10 young people employed one year after finishing school, were on a temporary contract in 2004. The same figure exceeded 50\% in Portugal, Sweden, France, Germany, Finland and Italy. At the opposite end of the scale, Iceland, the United Kingdom and the Slovak Republic had the lowest incidence of temporary employment one year after school ends. In 
addition, in some countries - notably Belgium, the Czech Republic, Portugal, the Slovak republic, and Spain - temporary work was mostly involuntary - i.e. youth would have liked a permanent job but it was not available.

Figure 10. Incidence of temporary employment among youths and prime-age adults in OECD countries, 1995-2005

Figure 11. Incidence of temporary employment one year after leaving school in Europe, 2004

29. Temporary work should not necessarily be equated with low-quality employment, as it may represent a stepping stone into the labour market and the pathway to permanent work, particularly for young people without labour market experience. However, so-called "temporary-work traps" may arise when youth accumulate temporary contracts rather than moving on to permanent jobs providing more training and career opportunities. To identify the countries where temporary-work traps may exist, Figure 12 shows the evolution of the incidence of temporary work over the past decade, for a synthetic cohort of youth aged 18 in 1995-1997. Although this is only an approximation of following the same individuals over time, the figure shows a clear tendency in all counties for youth to start working on temporary jobs but settle into permanent work later in life. Employed youth aged 18 at the beginning of the period are most likely to be in temporary jobs in Spain, Finland, France and Sweden, but while the share of temporary workers decreases over time in all four countries, it settles at different levels. In France, the share of 27-year-olds in temporary work in 2005 is just $13 \%$ while it stands at more than $45 \%$ in Spain. ${ }^{6}$ The profile is much flatter in other countries, particularly those with a lower incidence of temporary work. ${ }^{7}$

Figure 12. Share of persons aged 18 to 27 not in school and in temporary work by age, 1995-2005

30. The yearly rate of transition from temporary to permanent work - i.e. the proportion of youth on temporary jobs one year who are in permanent employment the following year - may also help in evaluating the existence of temporary-work traps. In Europe, between 1996 and 2001, this rate declined in a number of countries - notably Austria, Belgium, France, Germany, Greece and the United Kingdom (Figure 13).

Figure 13. Transition rates from temporary to permanent work in Europe, 1996-2001

Part-time work among the young

31. As well as entering the labour market on temporary positions, youth are also often working in part-time jobs, as shown in Figure 14. On average, 18.4\% of employed youth who left school in 2003 were employed in part-time jobs in 2004, 4 percentage points higher than at the end of the 1990s.

32. This indicator exhibits considerable variation, both across countries and gender. While less than $5 \%$ of employed youth one year after leaving school were working part-time in Hungary, the Czech Republic, and the Slovak Republic in 2004, this share exceeded 30\% in Denmark, the Netherlands, and Sweden. Also part-time rates are much higher for young women than for young men and much of the increase between the end of the 1990s and 2004 concerned women. Among women in Belgium, Denmark,

6. Note that since we are not following the same individuals over time, the differences at later ages could be due to the fact that those who enter the labour market later are more likely to be on temporary jobs in some countries than others - this could explain why Spain still has such a high share of temporary employment when the synthetic cohort reaches age 27.

7. Note that the slight bump observed in the mid-1990s in Italy and Portugal can be attributed to the liberalisation of the use of temporary contracts in both countries in 1995. 
Finland and Sweden, the rise exceeded 20 percentage points. Only in Finland and Sweden was this trend accompanied by a rise in part-time work among young men.

33. It is difficult to determine a priori whether a relatively large share of part-time work is a desirable development among youth. Indeed, the emerging picture for part-time is mixed. In Denmark and the Netherlands, part-time work coexists with very high employment rates and low unemployment rates among youth and it is mostly voluntary. In other countries such as Belgium and France - where the share of part-time work among school leavers is still relatively high - part-time is mostly involuntary and accompanied by high unemployment and low employment among youth.

Figure 14. Incidence of part-time one year after leaving school, 2004

\section{Low entry wages: a ladder to climb?}

34. Pay is another important dimension of job quality and one that is particularly relevant for young people who have no previous labour market experience and are more likely to be paid a low wage on their first job. While low starting wages can be justified on grounds that young people need training and work experience, the prospects of progression on the pay scale could be used as a measure of successful labour market insertion. In this respect, Figure 15 presents some indicators of pay dynamics - similar to those used for NEET in Figure 4 - of individuals aged 15-24, over a 5-year period, where low pay is defined as earning an hourly wage that is lower than two-thirds of the median gross hourly earnings of persons aged 25 to 54. All three indicators of low-pay incidence are highest in Greece, the United Kingdom, and the United States and lowest in Austria, Denmark and Italy.

Figure 15. Alternative measures of low-paid employment for youth, 15-24, over five years, 1997-2001

35. Many young people are affected by low pay at least once over the 5-year period under analysis in several countries more than $50 \%$, but high exit rates guarantee a relative high turnover rate. Indeed, both incidence and turnover are substantially higher for youth than for prime-age workers (see OECD 2003 for adult rates), and turnover in low-pay jobs tends to be higher than turnover in non-employment, pointing to more dynamism among working youth than among NEET youth (see Figure 4).

36. Panel B of Figure 15 gives more information on the duration and recurrence of low-pay experience among young people. Although it shows evidence for the existence of low-pay traps - with persons low paid in the first year (and working all five years) spending 2 to 3 years in low-paid employment in most European countries and in the United States - these are less likely than NEET traps (see Figure 4).

Figure 16. Low-pay incidence in Europe, 1995-2001

37. Finally, while Ireland, Spain and Portugal witnessed sharp falls in the incidence of low pay among youth between 1995 and 2001, in other European countries - notably Belgium, Finland, France, Germany, Greece, Italy, the Netherlands and the United Kingdom - the share of low-paid youth increased, sometimes markedly, over the same period (Figure 16).

\section{News from the policy arena}

38. The OECD has just begun a thematic review of policies to facilitate the transition of young people from school to work which will produce concrete, country-specific recommendations for the 15 or more OECD countries participating in the review. As a result, this section only looks at policy areas where there have been some interesting recent developments and is not intended to provide an assessment on what works and what doesn't. This includes recent initiatives to revive the apprenticeship system in 
Germany and new evidence on the effects of the United Kingdom's main active labour market programme for youth - the New Deal for Young People.

\section{1 "Dual systems" based on apprenticeships as a gateway to work}

39. Systems where class-based and work-based training are provided in parallel are known as "dual" systems. In a "dual" system framework - typical of Austria, Denmark, Germany, Switzerland and more recently Norway - youths spend some time in educational institutions and the remainder at the workplace. Apprenticeships are then part of the formal educational structure, and are usually entered into after completion of compulsory education. They involve an employment relationship plus formal schooling normally one and a half to two days per week - over a period of three or sometimes four years. At the end of the programme, apprentices graduate through a final examination in which they have to prove their theoretical and practical grasp of the occupation concerned (see Box 3 for a more detailed description of the German “dual” system).

40. Dual systems have proven quite successful in giving young people a good start in the labour market. Indeed, Denmark, Germany and Switzerland are among the OECD countries with the lowest unemployment rates for youth and Austria is still well below the OECD average for the same indicator (Figure 1). In addition, Austria, Denmark and Germany are among the countries with the lowest share of youth experiencing multiple unemployment spells (see Table 2). Avoiding early labour market difficulties is particularly important for youth as a rich literature shows that long unemployment experiences at labour force entry may have persistent negative effects on employment probabilities and wages later in life. ${ }^{8}$

41. Adding to an already rich literature, recent empirical findings provide further support for the idea that apprenticeships have a positive effect on early career unemployment outcomes. Van der Velden et al. (2001) also show that European countries with apprenticeship systems enjoy better youth employment patterns, particularly in terms of larger employment shares in skilled occupations and in high-wage sectors, than do those with little or no apprenticeship. Along similar lines, Gangl (2003) carries out a study of labour market outcomes of different types of school/work-based qualifications - including apprenticeships - for 12 European countries, and finds that apprenticeships perform rather favourably both compared to school-based education at the same level of training and across different qualification levels. Gangl also reports that, after controlling for institutional and structural factors, apprenticeships produce a significant reduction in early career unemployment rates (see also Ryan, 2001). Ryan (2001) and Steedman (2005) put forward the argument that part of this effect may come through a better matching of training to labour market demand that results from apprenticeship training being contingent on the offer of a place from employers. However, the evidence shows that effects of apprenticeship training on long-term employment outcomes and on post-apprenticeship wages are more mixed (see Ryan 2001).

\section{Box 1. Main features of the German "dual” system}

In Germany, people older than sixteen can enter the apprenticeship system, through which they are able to combine work-based and class-based training to acquire the vocational skills required on the labour market. Their preentry educational level does not formally determine their possibilities to enter the dual system, but it does influence their chance to find a training place.

Employers are not legally obliged to hire apprentices. But, if they do so, they must let them go to school during work time and have to provide the enterprise-based part of their training according to national standards - i.e. only a certified teacher, who has completed apprenticeship training and has obtained the Trainer Aptitude or the Meister certificate, is allowed to give enterprise-based training and the contents of enterprise-based training are determined

8. See Nerendranathan and Elias, 1993, Gregg, 2001, and Gregg and Tominey, 2005 for the United Kingdom, Balsam et al., 1996 for France, and Andress 1989 for Germany. 
per occupation. Over time, the ways to provide enterprise-based and school-based training have become more diverse. Nowadays, parts of enterprise training can be provided through extra plant training centres in order to improve the quality of training and to facilitate the provision of some parts of the training for small or medium-sized firms. ${ }^{a}$ And, on the other hand, some (larger) firms also provide the school-based part of the training within the firm.

Regulations related to the contents of enterprise-based training are determined at the federal level, jointly by government, employers and unions representatives. ${ }^{b}$ This is exceptional because almost all aspects of the education framework are regulated by the Länder, including legislation, regulations, curricula, standards, assessment procedures and quality control. While this implies that training curricula change slowly, it does not necessarily hinder the adaptability of individual firms to changing skill requirements, because regulations only relate to the provision of minimum standards. Individual firms can choose their own training methods and improve the required minimum training quality.

Training costs are shared between the government and employers: the governments of the Länder pay for the school-based component, while employers finance enterprise-based training, such as pay for apprentices, instructor salaries and equipment. The rules governing the payment of trainees are crucial in the functioning of apprenticeship programmes, as firms face large costs of apprenticeship training that might be lost because of turnover of trained workers after they finish their apprenticeship. As a result, low labour costs -and an appropriate division of funding responsibilities between public and private counterparts- are essential for a system of apprenticeship to work. The salaries of apprentices are relatively low - in the range of $25 \%$ to $45 \%$ of the average wage of a qualified worker in the same occupation (see Ryan, 2000). ${ }^{\mathrm{C}}$ The wage and working conditions for apprentices are determined per occupation, with collective bargaining agreements specifying the (minimum) apprentice wage. Thus, unions have been a key partner in the success of the apprenticeship system in Germany.

At the end of the apprenticeship period, qualifications are awarded on the basis of written and practical examinations, set and marked by external examiners. All parties - government, unions and employers - intervene in this final stage of the apprenticeship process. So-called competent bodies (mostly chambers of commerce) issue certificates, which are recognized throughout Germany. After graduation, workers can apply for a skilled worker's job with their current employer or look for a job with another employer. A job with the current employer is not guaranteed because apprentices have a labour contract of limited duration. Skilled workers also have the possibility to participate in adult education. On the labour market, there are clear links between the skilled worker status ('Facharbeiter') and the contents and status of a skilled worker job.

a) Public funds were used to build and equip these centres.

b) The institutional complexity of the German apprenticeship system requires government, employers and unions to work together at several stages in a cooperative way. As a result, a positive climate among these parties is essential to its success.

c) Similar systems of cost-sharing are in place in other countries that have successfully implemented vocational training systems. For instance, in Denmark and Ireland, statutory levy-grant systems redistribute part of the training costs to employers who do not provide training, but who stand to benefit from a higher stock of qualified labour. At the same time, apprenticeship pay tends to be higher in these countries than in Germany - notably, 51-54\% of workers carrying out the same tasks for Denmark and $60 \%$ for Ireland. What is clear is that the system has to be designed in a way that costs are shared by all the parties who benefit from apprenticeship training.

42. Despite working relatively well up to the end of the 1990s, the shortfall of openings for apprentices, particularly acute since 2000, has recently put strain on dual systems in countries with a long tradition of dual education. The labour market position of youth in these countries has worsened somewhat since and some analysts have started talking about a serious crisis in the system.

43. The number of apprenticeship places within the dual system depends heavily on the economic outlook for the country, and is also affected by the ongoing specialisation of companies. For instance, in Germany, companies that specialise in a small market segment are deemed unable to properly equip youth with all the skills required by the profession and are therefore not allowed to train apprentices. Rather than a mismatch in training places available and demanded, there is evidence for a structural mismatch between the broader educational requirements of apprenticeship education and those parts of the curriculum that an increasing number of companies can cover. 
44. Furthermore, some institutional features of the apprenticeship model make it difficult for firms to use it as product market competition increases. First, more and more companies find the effort and the responsibility of training an apprentice too high and, given the need to respond quickly to changing market conditions, an apprenticeship lasting three or more years is often seen as too long. This is particularly true for small and medium-sized enterprises which are hard to motivate to engage in training youth. As a result, many employers prefer to recruit skilled workers on the labour market than to train them through an apprenticeship. Finally, companies often complain that the low quality of compulsory schooling is not compatible with the growing skill requirements of the economy.

45. The lack of apprenticeship places is even more worrying if one considers that a large proportion of those not finding a place in the dual system consists of youth belonging to disadvantaged groups i.e. persons who could not fulfil the requirements of the apprenticeship contract because of physical or mental disabilities, youth with specific cultural or social problems, etc.

46. Faced with these problems, the German Government signed in 2004 an agreement with the social partners on lines of action to revive the apprenticeship system, the National Pact for Training and Young Skilled Staff (see Box 2). The aim of the agreement is to guarantee that a sufficient number of apprenticeship places are available by means of maintaining employers' interest and involvement. Adapting curricula to the training potential of firms as well as considering shorter apprenticeships are part of the Pact. This agreement also points to a central feature of the apprenticeship model at least in its European version: social dialogue. Indeed, the long history and institutional complexity of German apprenticeships leads one to conclude that it could have done so only in the presence of powerful employer associations, the full involvement of the unions and the long familiarity of all parties with the system.

47. Another potential way of increasing the supply of apprenticeship places is via public financing of further educational forms besides the dual system. It is important for young people who could not get an apprenticeship place to have the opportunity to enter high-quality vocational education and training if they so wish. This is the case of Norway where the " $2+2$ " scheme (so-called Reform 94, introduced in 1994) implies that students in vocational tracks spend two years in school and one or two years as apprentices in an enterprise. In Norway, it is the school authorities in each county that have to find a sufficient number of apprenticeship places to satisfy demand from students. If the places cannot be found, the authorities must, as an exceptional provision, arrange this part of the students` education to take place in school. Common curriculum plans for both the school part and the apprentice part of the vocational education have been developed. 


\section{Box 2. The National Pact for Training and Young Skilled Staff in Germany}

The lack of sufficient apprenticeship places was an issue in Germany for several years while demand continued to rise. In 2002, the number of apprenticeship places fell by 48,500 places and in 2003 , by another 15,000 . To look into the causes of this mismatch, a representative survey of 785 firms was conducted by the Cologne Institute of Business Research in spring 2004. The survey found that $61 \%$ of the establishments surveyed regarded more intensive advice for youths about their career choices as particularly important; $54 \%$ of them demanded that proficient trainees should have more opportunities during the training period to gain additional qualifications; $50 \%$ thought firms should have greater discretion in the organisation of their training; $47 \%$ wanted to see a greater emphasis placed on the practical aspects of the training within a shorter training period for those trainees performing well.

In response to these concerns, the German government started talks with trade unions and employer organizations, during which many of the points emerging from the survey were reiterated. The talks ended in June 2004 with the National Pact for Training and Young Skilled Staff (NPTYSS) which committed employers to offering sufficient apprentice places to meet demand over the following three years and the Government to reshape the apprenticeship framework. The Government committed to paying particular attention to employers' changing needs in reforming the system so that the system would be better adapted to new skill requirements and work organisation and would attract high-quality entrants.

Results came very quickly. In 2004, the German Ministry of Education recorded an increase in the total number of apprenticeship places available, the first increase since 2000 . However, more needs to be done to ensure that these improvements are not just transitory. To this end, since 2004 the Federal Government has been carrying out training campaigns jointly with Employment Agencies and Chambers of Commerce. The Training Campaign has focused on three main priorities: i) selected regions with a particularly poor supply/demand ratio or an above-average decrease in training places; ii) new growth branches, e.g. microsystems technology, nanotechnology, biotechnology and optical technology but also branches where more training places are offered than are demanded; and iii) specific groups, such as disadvantaged youth and young people and company owners with a immigration background.

One example of the initiatives taken under the NPTYSS is the so-called Jobstarter programme, managed by the Federal Ministry of Education and Research, which aims at: i) providing nation-wide funding for innovations and structural development in vocational education; and ii) a better regional supply of in-company training places for young people by means of motivating companies to provide training. The programme will focus on funding regional innovative and demand-oriented new initiatives (up to 100 million euros over 2005-2010), so that vocational training can be seen by employers as an instrument to cope with structural change. Jobstarter also strengthens regional responsibilities in training.

It is hard to say whether these initiatives will be successful in modernizing the apprenticeship system in a way that it overcomes its present crisis, but the fact that social partners' concerns are taken explicitly into account is a good augury of eventual success.

\subsection{Activation policies for youth}

48. Labour market programmes offer jobless and disadvantaged workers in general, and youth in particular, various mixes of job-search assistance, work experience, job training, remedial education and direct job creation. Over the past two decades, policy effort has focused more and more on the interaction between passive and active measures, following the "mutual-obligation" principle. In this respect, youth have often been a prime target group for active labour market policies (ALMPs).

Table 4. Public spending on youth labour market programmes, 1995-2002.

49. In about two thirds of the countries for which data are available (see Table 4), the share of ALMPs expenditure devoted to youth programmes increased between 1995 and $2002{ }^{9}$. In France, Portugal and the United Kingdom, more than a third of all expenditure on ALMPs went on programmes focusing on

9. Data on ALMP spending on special youth programmes are not available after 2002 due to a major change in the way in which Eurostat and the OECD classified these data. 
youth. Expenditure on youth ALMPs as a percent of total ALMPs expenditure has more than doubled in Australia, Austria, Germany, Japan, New Zealand, Sweden and Switzerland. It is noteworthy that in some of these countries - notably Austria, Germany, Switzerland and Japan - this higher expenditure came following a weakening of traditional school-to-work transition mechanisms. With the exception of Sweden, in countries where expenditure on youth programmes rose relative to adult ALMPs, the overall public spending on ALMPs rose as well.

50. As the expenditure data suggest, several countries have come to realise that, for those who are already out of the education system - particularly youth leaving school without an upper secondary qualification - active labour market policies, as opposed to passive ones, constitute the best option. However, while there is general agreement that focusing on activation and mutual obligation policies is the way forward (see OECD, 2006), this does not necessarily imply the proliferation of programmes, rather it should rest on a concentration on the most effective ones. This, in turn, puts a premium on knowing what works and what does not for youth. Drawing on the insights from rigorous evaluations of existing programmes is thus fundamental in highlighting what works and what does not and in setting guidelines for future action.

51. Pioneers in the activation approach to labour market policies, Nordic countries have attempted for many years to implement so-called "youth guarantees". ${ }^{10}$ Under such guarantees, the government commits itself to offer youths in a defined target group - which may be all who are registered unemployed and claiming unemployment insurance or social assistance benefits, or all who are not in education or employment in the years shortly after leaving school - a place in an education, training or work programme.

52. Evaluation results for such programmes vary widely, pointing to the varying effectiveness of the programmes in question as well as to fundamental issues of programme design and implementation (OECD, 2002). A study by Hamalainen and Ollikainen (2004) of ALMPs for youth in Finland indicates that job-placement into private sector jobs and short labour market training experiences (up to five months) are successful not only in promoting employment but also in increasing the earnings of participants. ${ }^{11}$ This is at odds with negative or zero returns to youth training programmes found for Swedish programmes. In fact, in Sweden, evaluations have shown that if activation programmes work better for youth than for adults, this is mostly due to pre-programme deterrence effects and/or more intense job-search support to youth from the public employment services before the programmes (see Forslund and Nordstrom Skans, 2006).

53. Australia's Mutual Obligation policy, in place since 1998, requires 18- to 24-year-olds (as well as 24-34 year-olds since 1999 and 35-49 year-olds since 2001) to undertake an additional activity after six months on unemployment benefits, and for 6 months of every 12 months spent on unemployment benefits. All job seekers in the target groups must participate in an interview at Centrelink - the Australian benefit agency - which informs them of the requirement to undertake an additional activity. Activities include

10. In 1984, Sweden introduced "the first genuine youth guarantee", followed by Norway in 1993 and Denmark and Finland in 1996. Some difficulties were encountered in implementing these guarantees at first and also in maintaining them through the recession of the early 1990s, but youth cohort sizes were falling and by the mid-1990s sufficient places to implement these guarantees were generally available, facilitating a shift to policies that require youths to participate in either education or the labour market. However, these "guarantees" did not rest on a mutual obligation cum activation approach and there is little rigorous evidence to suggest that they worked.

11. On the other hand, youth practical training - the largest and cheapest of all programmes in Finland, lasting up to 18 months and implying no employment contract with the employer providing the training - is not found to have any impacts on young people’s labour market trajectories. 
part-time work, voluntary work, education and training or participation in a community-based employment program - Work for the Dole - and failure to select and then complete a mutual obligation option may result in a cut in benefit payments.

54. Evaluations up to now have pointed to several weakness of the Australian Mutual Obligation programmes. Borland and Tseng (2004) find a negative effect of Work for the Dole on exits from unemployment during programme participation, although partial catch-up is observed for participants after they exit the programme. These disappointing outcomes can be blamed on the lack of focus on employment outcomes and on the limited involvement of private sector employers in the mutual obligation options. For example, Work for the Dole projects are selected on the basis that the work that they provide does not actively compete with jobs in the private sector. This requirement remains a problem as it favours unskilled work with little opportunity for training which may hinder the subsequent integration of the unemployed into productive work.

55. The New Deal for Young People (NDYP), introduced in the United Kingdom in 1998, is directed to youth who have been for a certain number of months on income support or unemployment benefits, and aims at providing them with several options to raise labour market involvement. Several evaluations show positive results (see Wilkinson, 2003, Blundell et al., 2001, and Van Reenen, 2003), in terms of higher employment probabilities for programme participants compared with a control group. See Box 3 for a more detailed description of the NDYP and recent evaluations of its effectiveness.

\section{Box 3. The UK's New Deal for Young People}

The New Deal for Young People (NDYP) was introduced in spring 1998 with the declared objective of improving employability of youth and helping them find a job. The programme is aimed at young people who have been claiming unemployment benefit (Jobseekers Allowance - JSA) continuously for six months. Participation is mandatory. Early entry to NDYP is possible and there are 11 groups who are entitled to enter NDYP before reaching the standard sixmonth entry point. Early entrants include people with disabilities, lone parents, ex-offenders, ex-members of the regular armed forces, people with literacy or numeracy problems and those meeting a range of other criteria.

Eligible job seekers are first put into a four-month programme called Gateway with a New Deal Personal Adviser. The purpose of this initial phase is to develop an individually tailored plan for improving the jobseeker's employability. At the end of the Gateway period, young jobseekers who have not found unsubsidized work can choose one of four options: subsidised full-time work; full-time education or training; work placement in the voluntary sector; or work with an environmental task-force. All options last up to six months, with the exception of the full-time education or training option which can last up to 12 months. Dorsett (2006), however, shows that many NDYP participants remained on the Gateway for longer than the maximum intended duration of four months, and never entered any of the options.

All these options continue to be subject to JSA rules, such as the obligation to actively seek work, irrespective of the financial arrangements for the specific option. If a young person completes or leaves an option and still has not obtained a job, they can reclaim JSA (if previously paid a wage) and enter the Follow-Through period. During FollowThrough, they receive further intensive help with job search in order to find a job, re-enter an option or even, in some cases, return to the Gateway.

A notable feature of the NDYP is the extent of involvement by employers. In 2000, 60,000 employers had already undertaken to provide employment opportunities for NDYP participants. This involves signing a New Deal Employer Agreement provided by the Employment Service. The agreement is a commitment to quality from both sides. It sets out the terms and conditions of the NDYP subsidised employment under which employers agree to treat NDYP employees in the same way as other employees and, wherever possible, to continue their employment after the end of the subsidy period, subject to commitment and aptitude. In return, the Employment Service promises to make subsidy payments accurately and on time.

Assistance available to employers in the UK consists of a subsidy of up to GBP 60 a week for six months and an additional contribution of up to GBP 750 is also available towards training of a young person. There is a strong emphasis on the obligation of employers to provide training leading to formal qualifications, with a strict requirement for employers to provide a minimum of one-day training a week which must lead to the equivalent of a National Vocational 
Qualification. This training can take place in the workplace or at a college. The training provided by employers is constantly monitored and reviewed and, if an employer is found not to be meeting these requirements, the subsidy is withdrawn.

Wilkinson (2003) estimates the impact of the NDYP on the probability of being unemployed six months after reaching the qualifying time for the programme - coinciding with movement from the Gateway period into the options. The results indicate, for men, a reduction in unemployment of around 30,000 and, for women, a reduction of around 9,000 . A longer follow-up period produces a lower reduction in the probability of being unemployed, mostly due to the fact that some NDYP participants would have returned to claim unemployment benefits subsequently. The same study also finds pre-programme effects, with 25,000 fewer young people remaining unemployed for six months in the year after the introduction of the NDYP than in the preceding two years. As for overall changes in employment, the paper finds no overall effect for men and an increase in women leaving unemployment for work of about 3,000.

Another study, by Blundell et al. (2001), finds that the impact of the NDYP on the exit rate from unemployment to employment after four months spent in the Gateway stage is a $20 \%$ higher probability of finding a job, with most of this gain being due to the subsidised employment option. Dorsett (2006) also finds that the subsidised employment option dominates the others: one and a half years after entry to an option, those on the subsidised employment one were 5 percentage points less likely to be unemployed than had they remained on the Gateway, and 16-19 percentage points less than had they entered one of the other three options.

A recent report from the National Centre for Social Research in the UK highlights the importance of the Gateway process. The report collects evidence showing that young people see the key to the success of NDYP as the personal relationship between the Personal Adviser and the jobseeker. The study also noted that the effectiveness of Gateway stems from ensuring that people are not forced into accepting any job but are matched to the one that suits them. Other important aspects of NDYP options reported on favourably by young people were the experience gained under the employment option, good work-based training opportunities to develop skills and gain qualifications through the full-time education and training option, and continued support once in a job.

On the negative side, some researchers argue that the programme's flexibility in offering youth different options to exit unemployment only applies in theory. Indeed, the choice for those youth particularly at risk of repeated spells of unemployment and inactivity remains restricted to those options that are less likely to help them get unsubsidized employment.

56. Trying to sum up what works and what does not is an arduous task but drawing on surveys of the evaluation literature, successful programmes appear to share some characteristics (see Martin and Grubb, 2001, and Betcherman et al., 2004):

- Early action is particularly important for young people as those without work experience are generally not entitled to unemployment benefits or other welfare transfers. ${ }^{12}$ A number of OECD countries already have major programmes for youths that come into play early, often before or at six months of unemployment, e.g. Australia, Belgium, Denmark, New Zealand, Norway and the United Kingdom. Sweden uses a shorter period (90 days), and youth activation in Finland, for those without a vocational qualification, starts immediately.

- In terms of content, job-search assistance programmes are often found to be the most costeffective for youth, providing positive returns on both earnings and employment. On the other hand, some employment subsidy programmes do yield positive returns, but they generally tend to perform poorly in terms of their net impact on the future employment prospects of participants.

12. For instance, in France, 6 months of work are required before entitlement is attained and only 25-year-olds or older are entitled to the means-tested minimum income benefits (RMI). Also, in Belgium school leavers are entitled to unemployment benefits of effectively unlimited duration, even without previous contributory history but only after one year of non-employment. 
- Training programmes should be designed in connection with local or national labour market needs. In this respect, mobilizing and involving the private sector and communities to assess local or national demand for skills and community needs is most important to project design.

- Good targeting of the programmes is also crucial. For instance, there is a need to distinguish between teenagers and young adults and to focus on early school drop-outs. Specifically, the most desirable solution to the employment problems of teenagers is to help them to remain in school and acquire educational qualifications, whereas for young adults, help to acquire work experience is more important.

- Tight work-search requirements tend to encourage early exit from unemployment, as much for youths as for adults. Indeed, in Australia, when "mutual obligation" requirements were applied to youths who had been unemployed for six months, an increase in the rates of exit from unemployment was observed (see QED, 2003).

- Programmes that integrate and combine services and offer a comprehensive "package" seem to be more successful.

- Greater involvement of the social partners, as well as the public authorities at all levels, can help enhance the effectiveness of programmes. A tightly controlled system of certification to ensure the quality and relevance of training programmes may also contribute to the same goal (OECD, 1996 and O’Higgins, 1997).

57. Two weaknesses of ALMPs for youth remain unaddressed: they can be rather expensive, and even the best performing programmes have found it extremely difficult to tackle the problem of very disadvantaged youth. With regard to the former, particularly when spending is high, policy assessments need to consider how far any reduction in unemployment has come at the cost of an increase in "hidden" or "disguised" unemployment - i.e. individuals who exit unemployment to participate in unproductive or excessively lengthy education and training. It may be possible to limit costs if, faced with an activity obligation, some young unemployed people find an unsubsidised job instead and relatively few enter expensive job-creation options.

58. As mentioned above, even the best performing programmes, when evaluated, often fail on their ability at helping the most disadvantaged youth. This is the case, for example, for the UK's NDYP. The most effective option made available to participants in this programme appears to be subsidized privatesector employment. However, this option is often available to youths who would have exited unemployment even in the absence of the programme. And, youth at high risk of labour market exclusion are most often directed to subsidized jobs in the non-profit sector or other options less likely to favour fulltime permanent employment. For this reason, the NDYP programme has been accused of increasing labour market segregation for those youth who are most at risk, by sanctioning them when they are not successful in getting permanent employment (see Glyn and Wood, 2001).

59. What has emerged from evaluation of several programmes is that the neediest youth need to be identified as early as possible during the unemployment experience and provided with specific attention and focused - as far as possible, personalised - help. Among programmes targeted specifically to disadvantaged youth, there is evidence that residential programmes may yield positive private and social returns. Job Corps in the United States is a notable example of such a programme. It consists in taking disadvantaged youth aged 16-24 out of their regular locality and putting them into a boarding-school type environment, giving them mentoring, work experience and remedial education. Several rigorous 
evaluations $^{13}$ have found that Job Corps has yielded positive labour market returns - both in terms of employment and wages - as well as high social returns (including favourable effects on crime, drug use and violence).

\section{Conclusions}

60. First, the overall picture with regard to developments in the youth labour market over the past decade is a mixed one. Some key indicators point to small improvements in performance, others point in the opposite direction. Some countries have also recorded an improvement in youth labour market performance while others have not. The youth labour market is characterised by much turnover between the states of employment, unemployment and inactivity (which can include enrolment in education). The length of the transition from school to work varies significantly across countries: it can take up to two or more years before many school leavers find their first job. Some young people, particularly those with low educational attainment, can find it very hard to escape from spells of unemployment/inactivity punctuated by spells of employment, often on temporary contracts. Many others, however, progress fairly smoothly into jobs with good career prospects.

61. Countries use a variety of instruments to improve the labour market situation of youth. There is agreement that, in order to improve youth job prospects, it is essential to combat school failure. In particular, early and sustained intervention can help prevent a vicious circle of cumulative disadvantages. Most countries have only started to tackle the issue, mostly through reforms of initial education aimed at guaranteeing equity of its provision and by reinforcing vocational education for students not attracted to general studies.

62. Second, apprenticeship and dual-type systems, traditionally found in Austria, Denmark, Germany and Switzerland, have proven successful in giving young people a good start in the labour market (although longer-run effects have been shown to be limited). This helps explain why these countries enjoy relatively low youth unemployment rates. Recently, however, concern has been expressed, especially in Germany, as to whether employers in these countries will continue to offer a sufficient number of apprenticeship places. As a result, particular attention should be paid in dual-type systems to the existence of sufficient incentives for employers' participation - such as an apprenticeship pay level that offsets the cost of the training effort - and to the creation of high-quality classroom-based vocational education for those young people who may not get an apprenticeship place. In general, the difficulty of instituting or expanding dual-type systems in other countries is not to be underestimated, as such systems rest on the presence of powerful employer associations and the active involvement of all social partners.

63. Third, there is increasing recognition of the importance of activation strategies for promoting employment prospects of unemployed youth. Some of the most ambitious and comprehensive programmes - notably the New Deal for Young People in the United Kingdom - seem to have been successful in helping participants find a job. These programmes should focus on job-search assistance, often found to be the most cost-effective programme for youth. Besides, where training is envisaged, it should be designed with labour market requirements in mind. Finally, good targeting and tight work-search requirements are important design features to help contain overall costs while guaranteeing focus on the needy. Work remains to be done in terms of evaluation and monitoring, especially in terms of the ability of active labour market programmes to help the most disadvantaged youth find a job. For the latter group, some U.S. studies suggest that residential programmes - where youth are taken away from their neighbourhood and given mentoring, work experience and remedial education - may yield significant improvements in labour market and social outcomes, leading to high social rates of returns.

13. See Schochet et al. (2000 and 2001) and Lees (2005). 
64. Finally, supply-side policies need to be complemented with policies aimed at increasing job creation in general and at removing obstacles to hiring young people in particular. The hiring of young workers is likely to be hampered by certain institutional settings favouring insiders and by high labour costs that may discourage employers from hiring workers with high training needs. The introduction of sub-minimum wages for youth may help in this regard, and such a sub-minimum wage may need to be complemented with in-work benefits in order to reduce the risk of poverty while also making work more financially attractive than remaining on benefits and/or being supported by the family. In addition, wellconceived reforms to employment protection legislation that avoid the risk of labour market duality may help youth enter the labour market without an undue risk of getting locked into temporary-job traps. 


\section{BIBLIOGRAPHY}

Andress H. (1989), "Recurrent Unemployment - The West German Experience: An Exploratory Analysis Using Count Data Models with Panel Data”, European Sociological Review, Vol. 5 No. 3, pp. 275297.

Balsan D., S. Hanchine, and P. Werquin (1996), "Mobilité Professionelle Intiale: Éducation et Expérience sur le Marché du Travail”, Économie et Statistique, Sept., pp. 91-106.

Betcherman, G., K. Olivas, and A. Dar (2004), "Impacts of Active Labour Market Programs: New Evidence from evaluations with particular attention to developing and transition countries”, World Bank Social Protection Discussion Paper, No. 0402, Washington DC.

Blundell, R., C. Meghir, and J. Van Reenen (2001), "Evaluating the Employment Impact of a Mandatory Job Search Assistance Program”, The Institute for Fiscal Studies, Working Paper 01/20, December.

Borland, J., and Y. P. Tseng (2004), “Does ‘Work for the Dole’ Work”, Melbourne Institute Working Paper, No. 14/04.

Brinton, M. (2000), "Social Capital in the Japanese Youth Labour Market: Labour Market Policy, Schools, and Norms”, Policy Sciences, Vol. 33, No. 3-4, p. 289-306.

Cardoso, A.R. (2004), “Jobs for Young University Graduates: Is It Worth Having a Degree?”, IZA Discussion Paper No. 1311.

Chiswick B., and P. Miller (1985), “Immigration Generation and Income in Australia”, Economic Record, Vol. 61, p. 540-543.

Cologne Institute for Business Research (2004), “Duale Berufsausbildung: Ein Erfolgsmodell”, Jg. 30, Nr. 43, July.

Dorsett, R. (2006), “The New Deal for Young People: Effect on the Labour Market Status of Young Men”, Labour Economics, vol.13, pp. 405-422.

Ekberg J., and D. Rooth (2003), "Unemployment and Earnings for Second-Generation Immigrants in Sweden”, Journal of Population Economics, Vol. 16, p. 787-814.

Forsland, A., and O. Nordström Skan (2006), "Swedish youth labour market policies revisited “, Vierteljahrshafte zur Wirtschaftsforschung, vol. 75, No. 3, pp. 168-185.

European Commission (2000), “Tax and Benefit Reform in the UK: Making Work Pay”, HM Treasury Paper, London.

Gangl M. (2003), "Returns to Education in Context: Individual Education and Transition Outcomes in European Labour Markets”, in W. Muller and M. Gangl (eds.), Transitions From Education to Work in Europe - the Integration of Youth into EU Labour Markets, Oxford University Press, Oxford. 
Gregg P. (2001), “The Impact of Youth Unemployment on Adult Unemployment in the NCDS”, Economic Journal, Vol. 111, pp. 623-653.

Greeg P., and E. Tominey (2005), “The Wage Scar from Male Youth Unemployment”, Labour Economics, Vol. 12, pp. 487-509.

Glyn A., and S. Wood (2001), “New Labour’s Economic Policy”, Political Quarterly, January.

Hamalainen K., and V. Ollikainen (2004), "Differential Effects of Active Labour Market Programmes in the Early Stages of Young People's Unemployment”, Government Institute for Economic Research, Helsinki, Working Paper 115.

Hardoi I. (2005), "Impact of Multiple Labour Market Programmes on Multiple Outcomes: the Case of the Norwegian Youth Programmes”, Labour, Vol. 19, pp. 425-467.

Honda, U. (2003), "The Reality of the Japanese School-to-Work Transition System at the Turn of the Century: Necessary Disillusionment”, Social Science Japan, February, pp. 8-12.

Lees D. S. (2005), "Training, Wages, and Sample Selection: Estimating Sharp Bounds on Treatment Effects", NBER Working paper 11721.

Martin J.P., J.M. Evans and W. Franz (1984), "Youth Labour Market Dynamics and Unemployment: An overview", in J. Martin (ed.), The Nature of Youth Unemployment, OECD, Paris.

Martin J.P., and D. Grubb (2001), "What Works and for Whom : a Review of OECD Countries' Experiences with Active Labour Market Policies”, Swedish Economic Policy Review, Vol. 8, No. 2. pp. 9-56.

Mitani N. (1999), “The Japanese Employment System and Youth Labour Market”, in Preparing Youth for the $21^{\text {st }}$ Century: the Transition from Education to the Labour Market, OECD, Paris.

Mitani N. (2005), "Youth Employment after the Bubble Burst in Japan”, mimeo, Graduate School of Economics, Kobe University, Japan.

Nerendranathan W., and P. Elias (1993), "Influences of Past History on the Incidence of Youth Unemployment: Empirical Findings for the UK”, Oxford Bulletin of Economics and Statistics, Vol. 55, pp. 161-185.

O’Higgins, N. (1997), “The Challenge of Youth Unemployment”, ILO Employment and Training Working Papers, No. 7, Geneva.

OECD (1983), Employment Outlook, Paris.

OECD (1994), The OECD Jobs Study: Facts, Analysis,Strategie, Paris.

OECD (1996), Employment Outlook, Paris.

OECD (1997), Employment Outlook, Paris.

OECD (1998), Employment Outlook, Paris.

OECD (1999), Employment Outlook, Paris. 
OECD (1999b), Preparing Youth for the $21^{\text {st }}$ Century: The Transition from Education to the Labour Market, Paris.

OECD (1999c), Thematic Review of the Transition from Initial Education to Working life, Country Note: Sweden, OECD.

OECD (2000) Thematic Review of the Transition from Initial Education to Working Life, Paris.

OECD (2002), Employment Outlook, Paris.

OECD (2003), Employment Outlook, Paris.

OECD (2004), Employment Outlook, Paris.

OECD (2006), Employment Outlook, Paris

QED (Quod Erat Demostrandum) (2003), “Good Practices in Social Inclusion and Active Labour Market Programs for Youth”, Mimeo.

Ryan, P. (2000), "The Attributes and Institutional Requirements of Apprenticeship: Evidence from Smaller EU Countries”, International Journal of Training and Development, Vol. 4, No. 1, pp. 42-65.

Ryan, P. (2001), “The School-to-Work Transition: A Cross-National Perspective”, Journal of Economic Literature, Vol. 39, No. 1, pp. 34-92.

Ryan, S. (2003), "Provision of Junior Certificate, NCVA and Leaving Certificate Programmes 2003: Data Analysis and Report”, National Co-ordinators, YOUTHREACH and Senior Traveller Training Centres.

Schochet P., J. Brughardt, and S. Glazerman (2000), National Job Corps Study: The Short-Term Impacts of Job Corps on Participants' Employment and Related Outcomes", Washington DC, US Department of Labour Employment and Training Administration.

Schochet P., J. Brughardt, and S. Glazerman (2001), National Job Corps Study: The Impacts of Job Corps on Participants' Employment and Related Outcomes", Princeton, NJ: Mathematica Policy Research, Inc.

Steedman H. (2005), “Apprenticeship in Europe: Fading or Flourishing?”, Centre for Economic Performance discussion paper No. 710.

Tang Z., and M. Brinton (2003), “Institutional Change in the Japanese Youth Labour Market”, mimeo, Cornell University, Ithaca.

Tsang M., R. Rumberger, and H. Levine (1991), “The Impact of Surplus Schooling on Worker Productivity”, Industrial Relations, Vol. 30, No. 2, pp. 209-228.

Van der Velden R., R. Welter, and M. Wolbers (2001), “The Integration of Young People into the Labour Market within the European Union: the Role of Insitutional Settings”, Research Centre for Education and the Labour Market working paper No. 2001/7E

Van Reenen, J. (2003), “Active Labour Market Policies and the British New Deal for the Young Unemployed in Context”, NBER working paper No. 9576. 
Verhaest D., and E. Omey (2004), “What Determines Measured Overeducation?”, Univeriteit Gent, Faculteit Economie En Bedrijfskunde, Working Paper 2004/216.

Wilkinson, D. (2003), “New Deal for Young People: Evaluation of Unemployment Flows”, Policy Studies Institute, Research Discussion Paper 15. 
Figure 1. Unemployment and employment rates of youth in OECD countries, 1995 and 2005
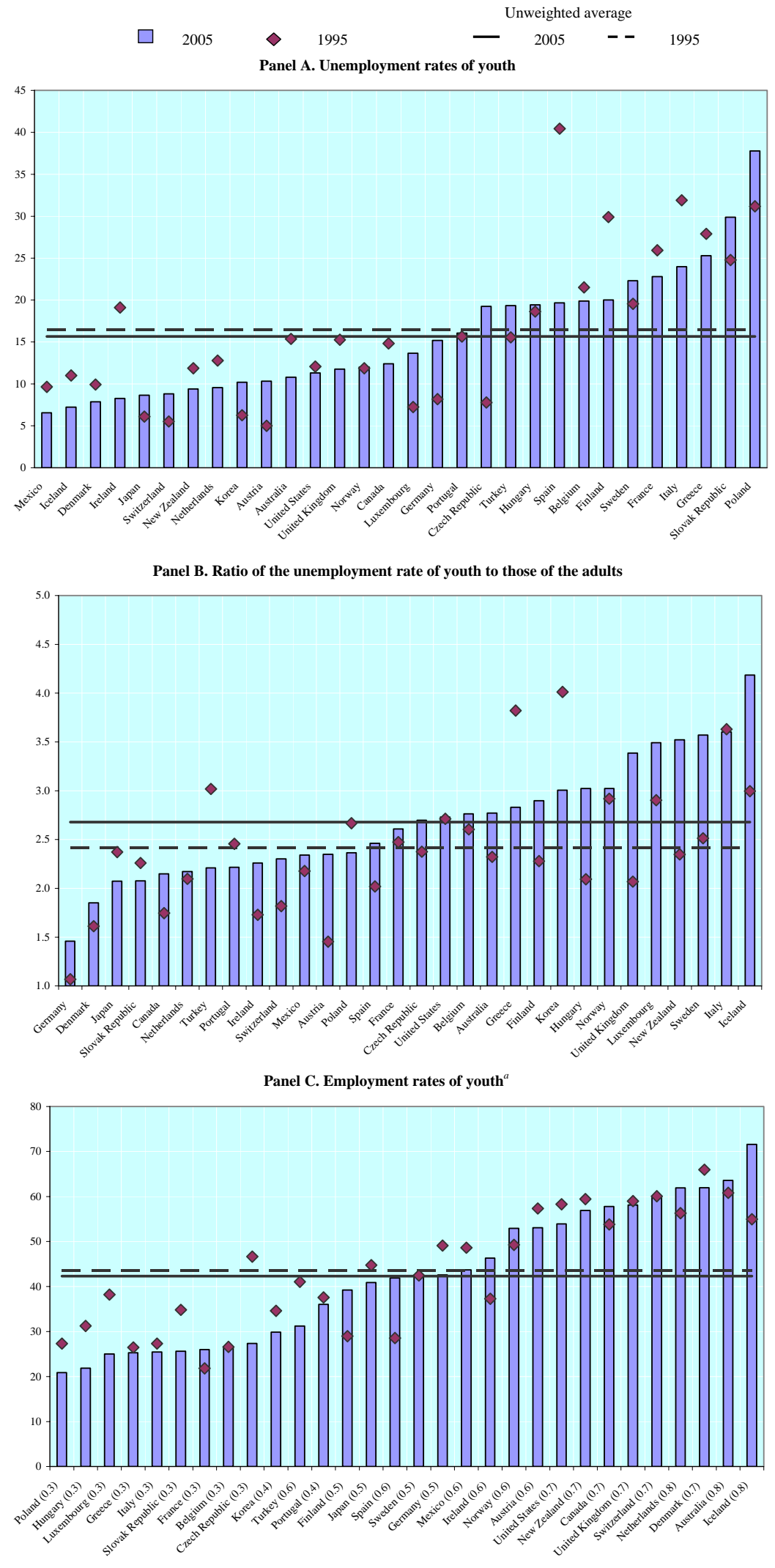
Figure 2. Share of teenagers and young adults neither in education nor in employment, 1996-2003 ${ }^{a}$ Percentages

$2003 \quad$ U Unweighted average in 2003

Teenagers (15-19)
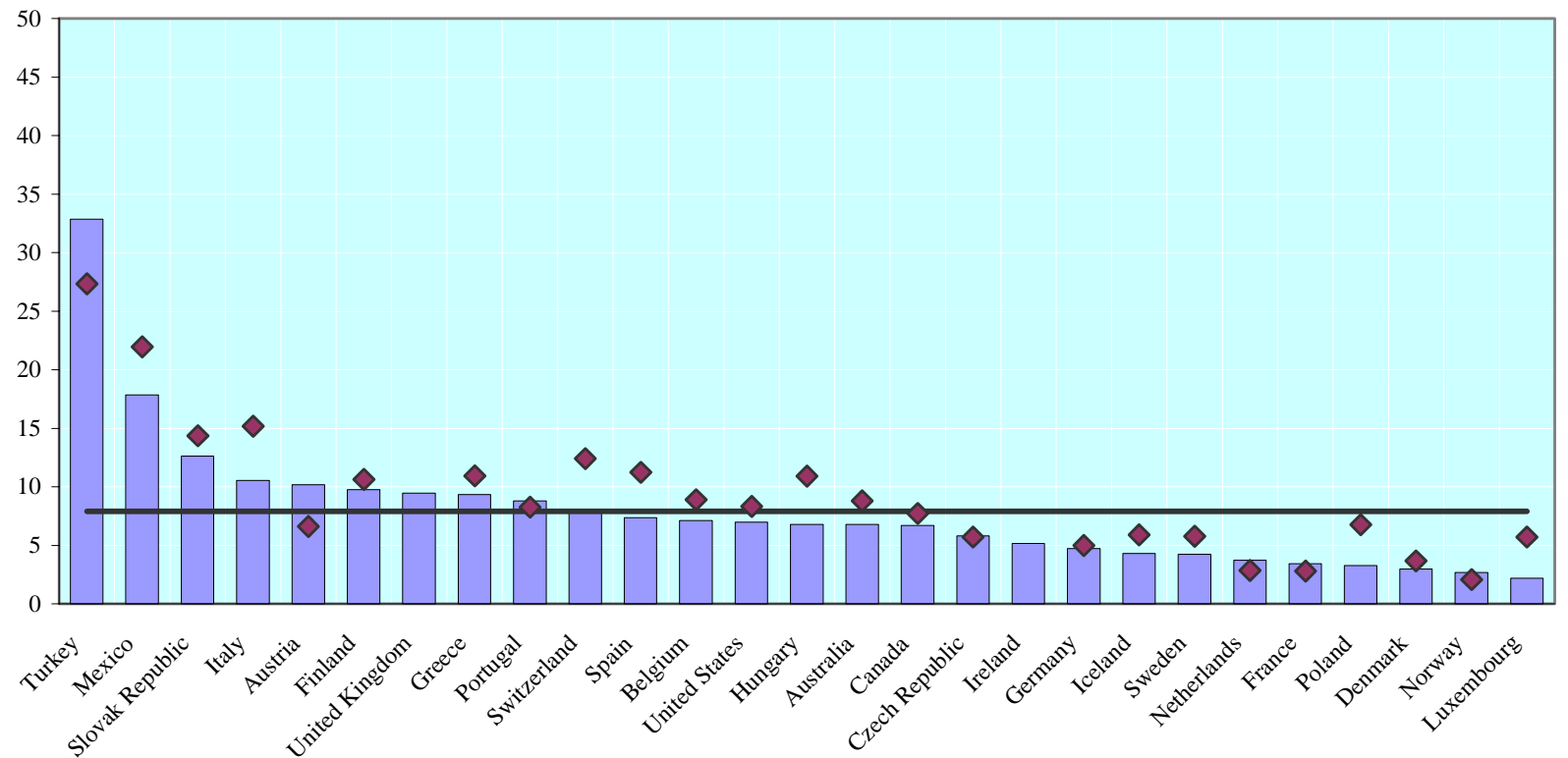

Young adults (20-24)

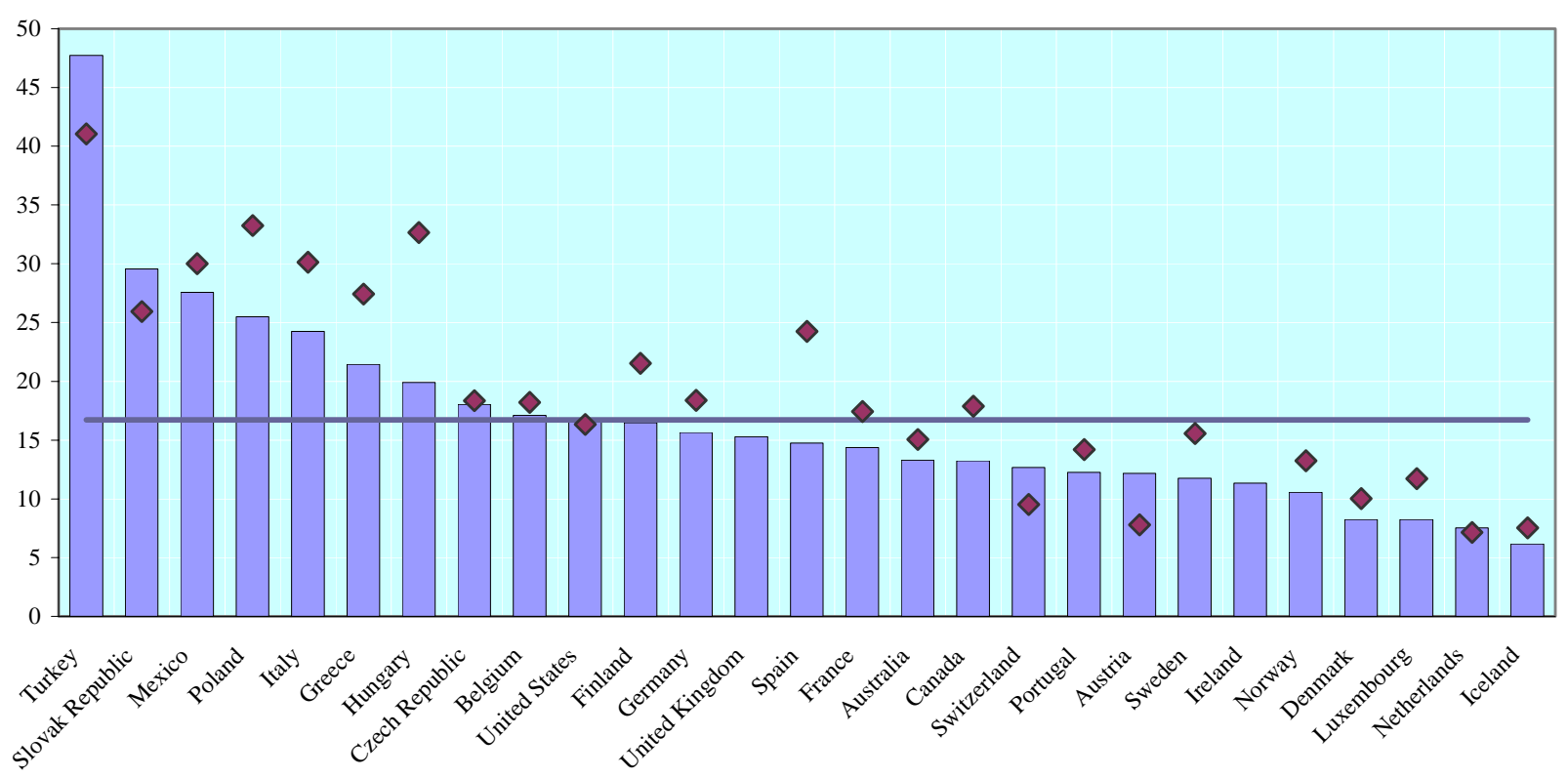

a) For France, Iceland, Italy and the United States, data refer to 2002 instead of 2003; for Germany, Finland and the Netherlands, data refer to 1997 instead of 1996; for Austria and Italy data refer to 1998 instead of 1996. For Ireland and the United Kingdom, data are not available for 1996. Source: OECD database on Labour Market Status by Educational Participation. 
Figure 3. NEET rates by educational level and gender, $2003^{a}$

Share of youth aged 15 to 24 neither in education nor in employment, by gender and level of education ${ }^{b}$

$\square \quad$ Men

$\square$ Women

Less than upper secondary
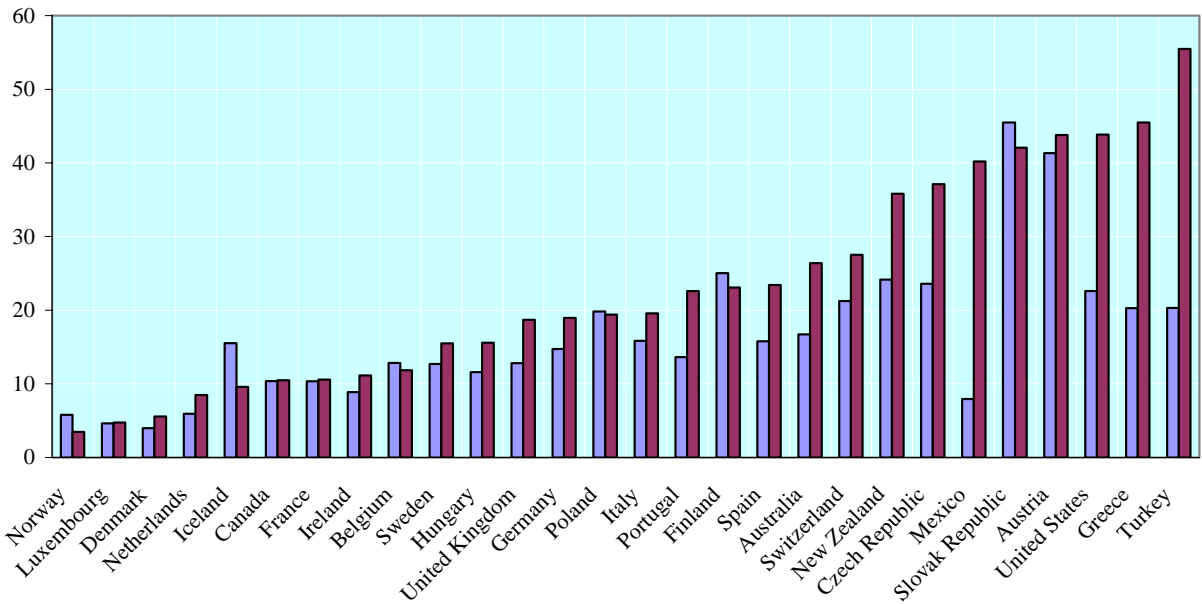

Upper secondary
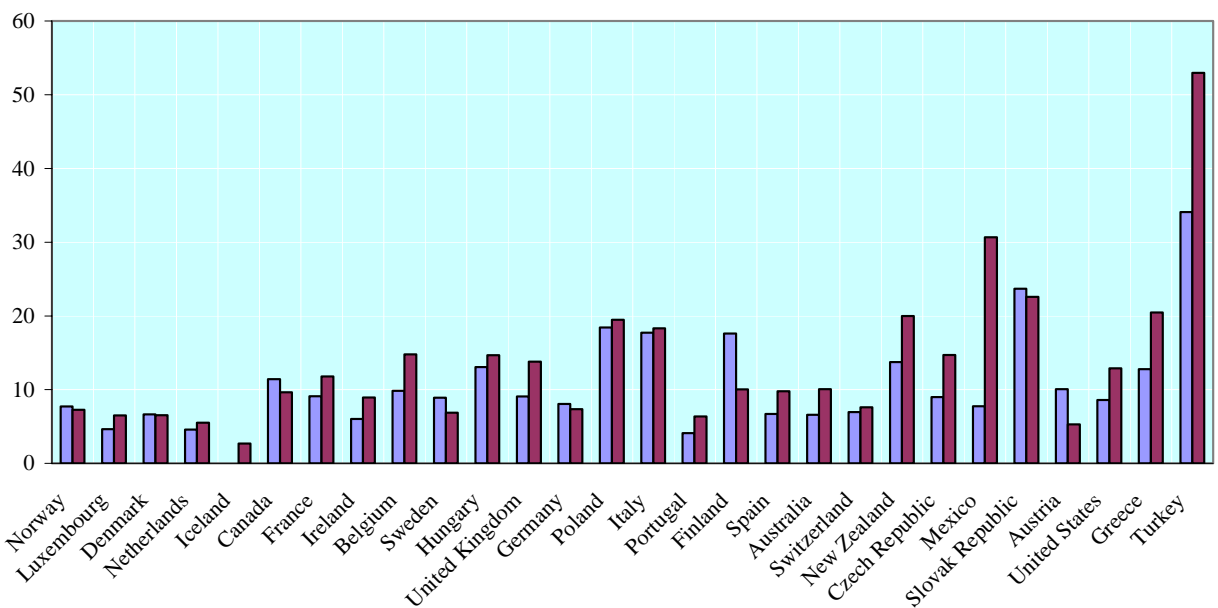

Tertiary

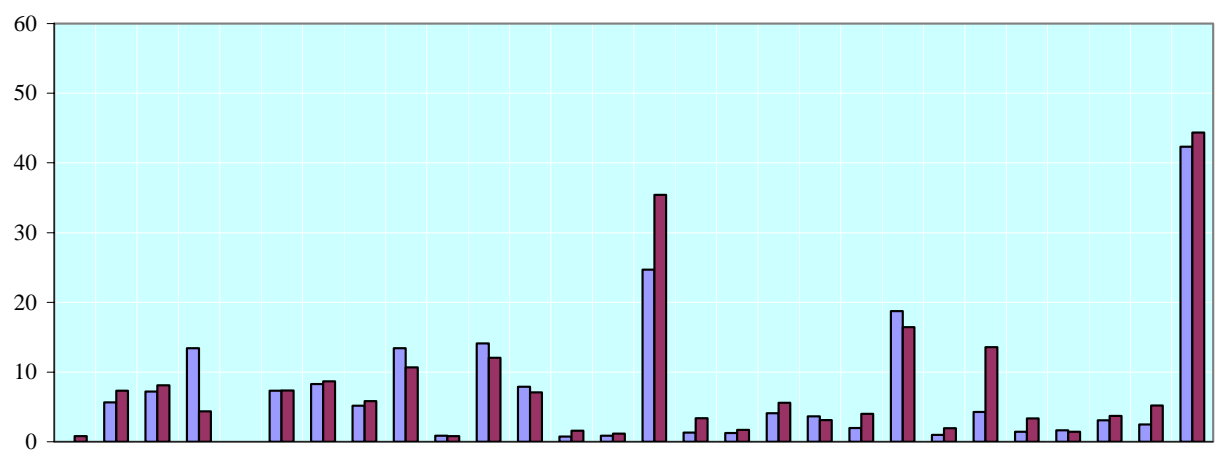

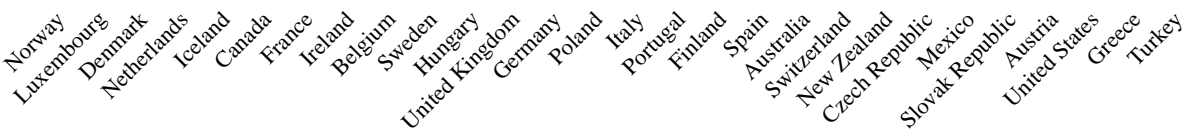

a) For Iceland, Italy, the Netherlands and the United States, data refer to 2002; for New Zealand data refer to 2001

b) Countries are ranked by ascending share of women aged 15 to 24 neither in education nor in employment.

Source: OECD database on Labour Market Status by Educational Participation. 
Figure 4. Alternative incidence measures of NEET status of youth over the period 1997-2001

Panel A. Percentage of youth neither in employment and nor in education ${ }^{a, b, c}$
Ever NEET
Annual NEET rate
Always NEET

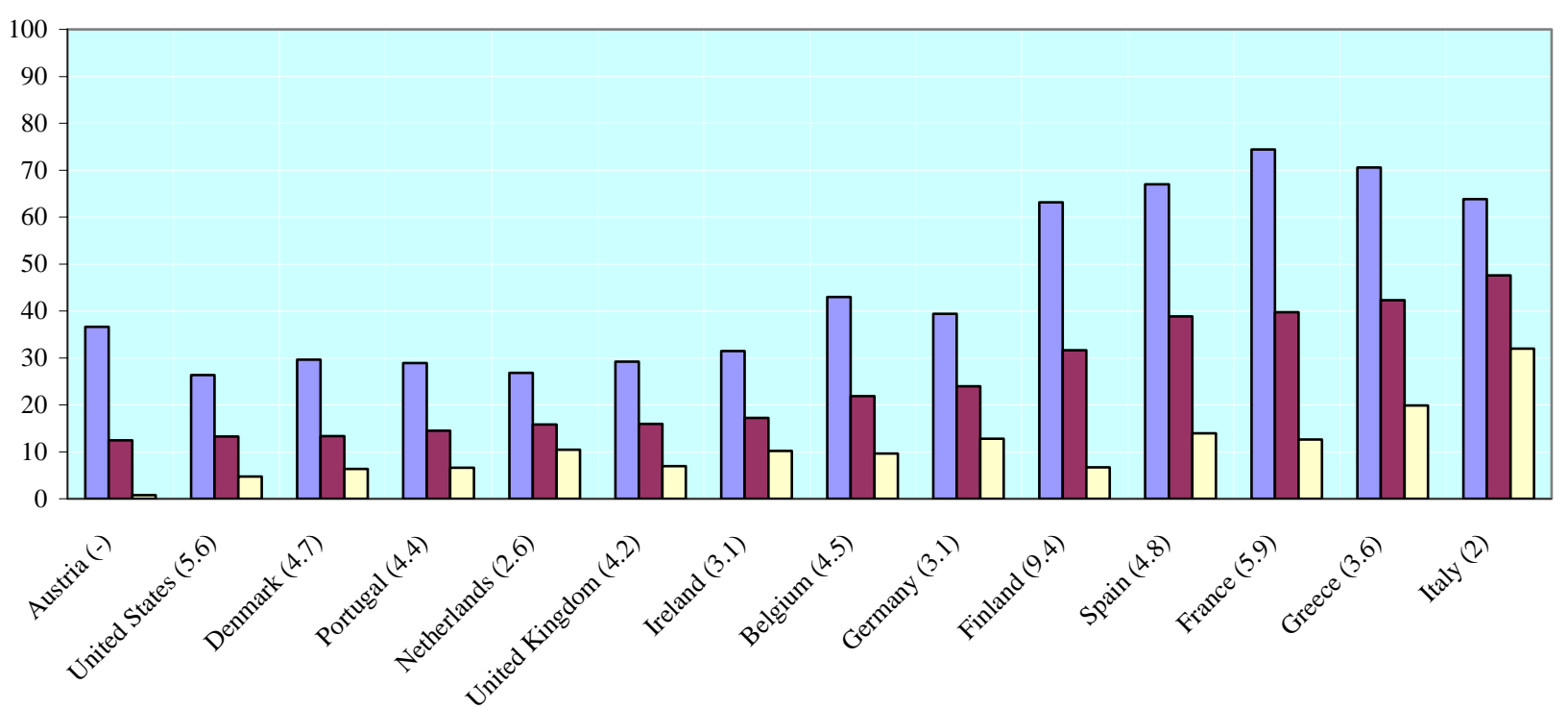

Panel B. Five-year experience of youth neither in employment and nor in education in the first year
NEET years ${ }^{d}$ (left side scale)
- Exit rate $^{e}$ (right-side scale)
- Recurrence rate ${ }^{f}$ (right-side scale)

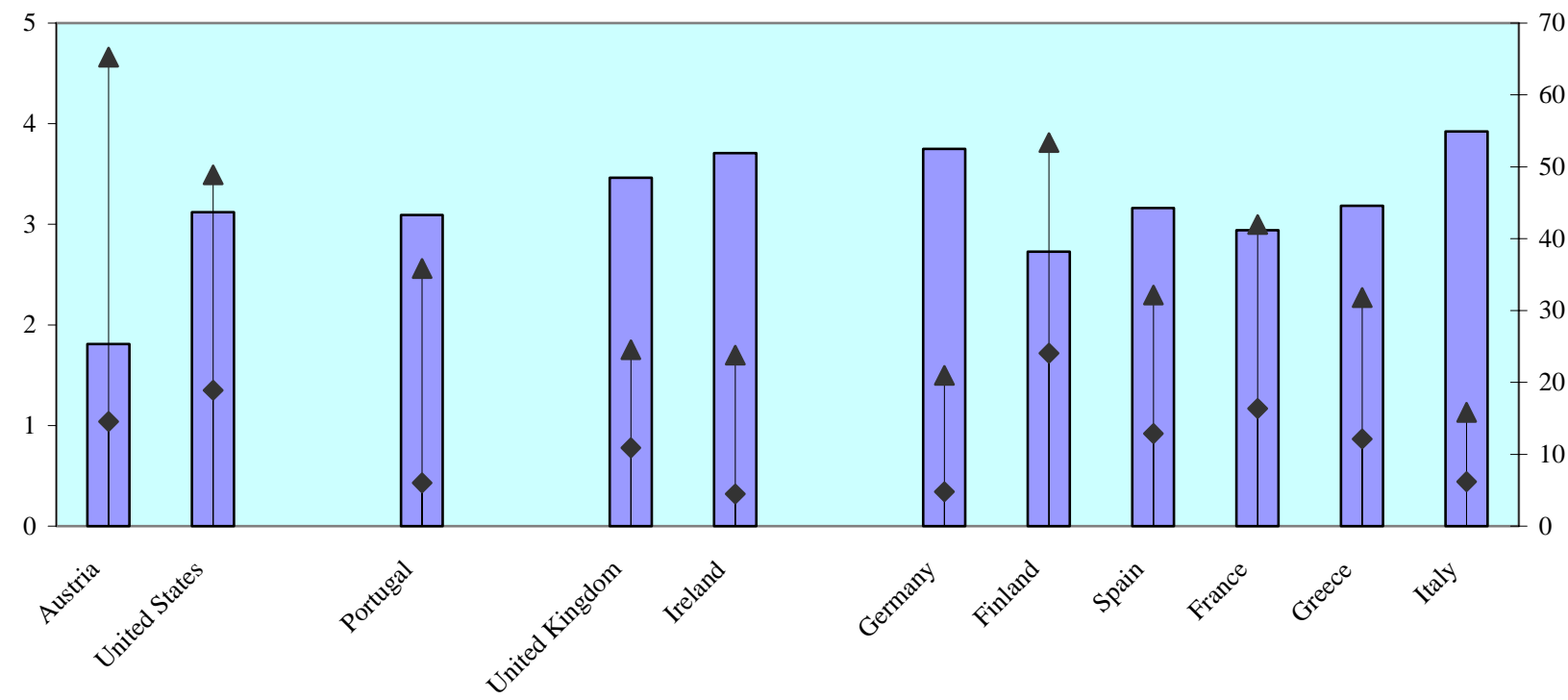

a) Countries shown in ascending order of single-year of NEET (Panel A).

b) Values within parenthesis below the country labels in Panel A are the ratio of the ever to always NEET rates (an index of turnover in status).

c) The sample excludes the persons in education.

d) Annual average.

e) Share of 1997 NEET persons who were employed in 1998.

f) Share of 1997 NEET persons who were employed in 1998 but experienced a repeat spell of NEET during the next three years.

Source: OECD Secretariat estimates based on the European Community Household Panel, waves 4 to 8 (1997-2001), for the European countries and based on the Survey of Program Dynamics (SPD) 1997-2001, for the United States. 
Figure 5. Incidence of long-term unemployment among youth

Long-term unemployment as a percentage of total youth unemployment ${ }^{a}$

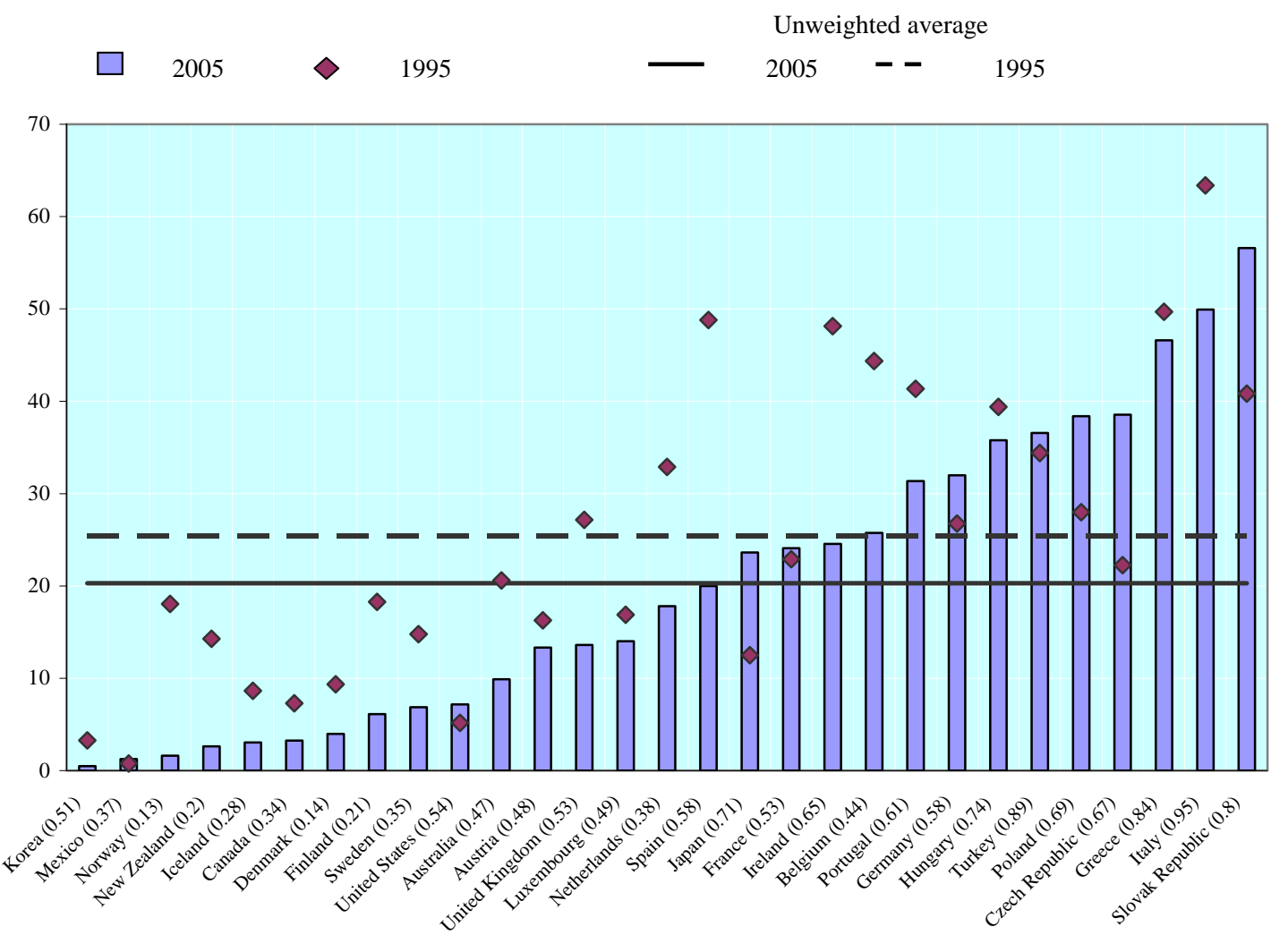

a) Values within parenthesis are the ratio of the incidence of long-term unemployment among youth (15-24) to those of adults (25-54) in 2005 b) 2004 for Iceland and Sweden.

Source: OECD database on Unemployment Duration. 
Figure 6. Job hires and job changers, ${ }^{a} 2004$

Percentage of all employed persons in the corresponding age group one year earlier $15-24$ 25-49
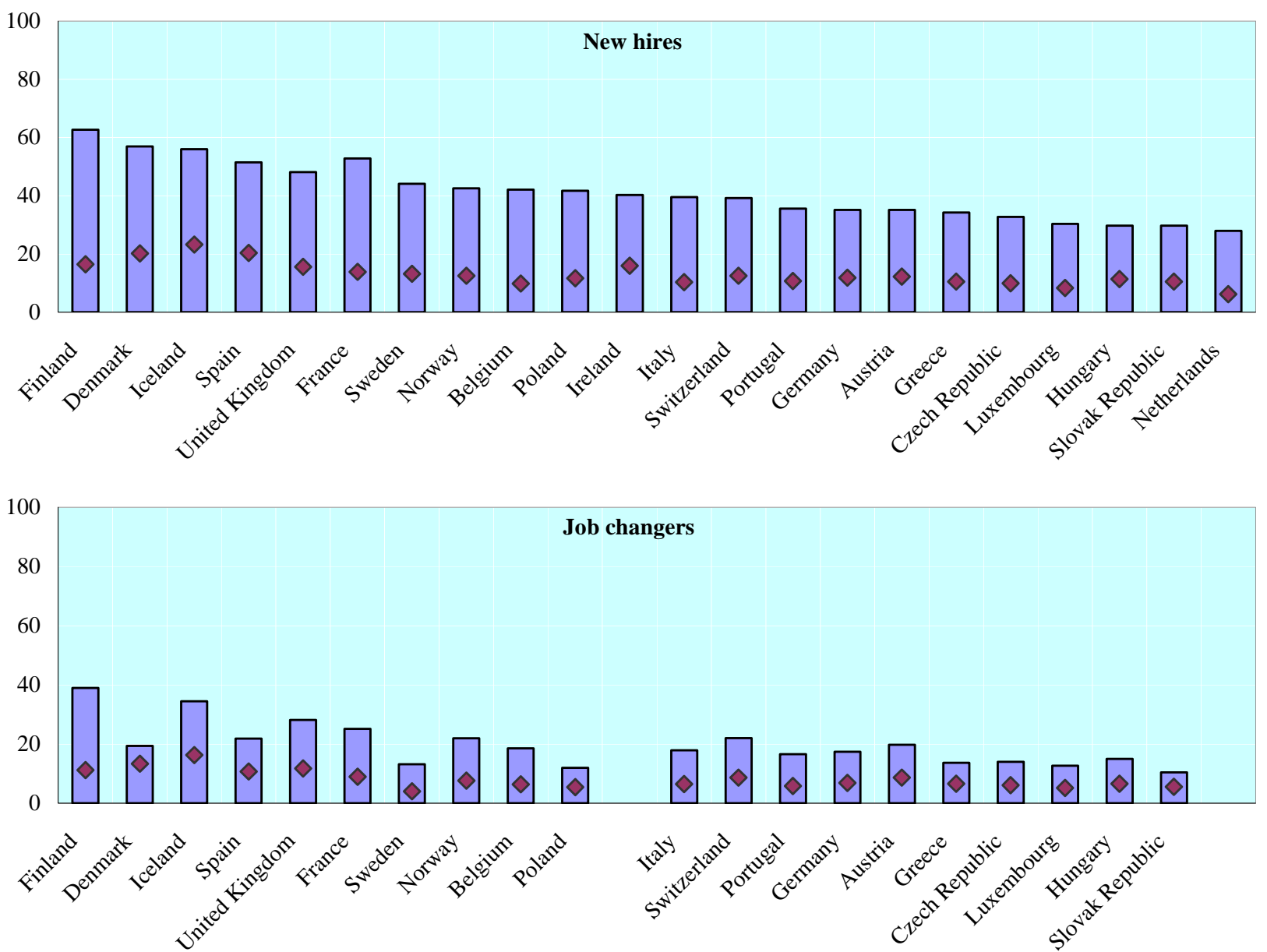

a) New hires refer to all workers at the time of the survey with job tenure of less than one year. Job changers refer to those newly hired workers who were also employed one year before.

Source: OECD Secretariat calculations based on the European Union Labour Force Survey. 
Figure 7. Job quits and job losers, ${ }^{a} 2004$

Percentage of all employed in the previous period

$\square \quad 15-24$

$25-49$
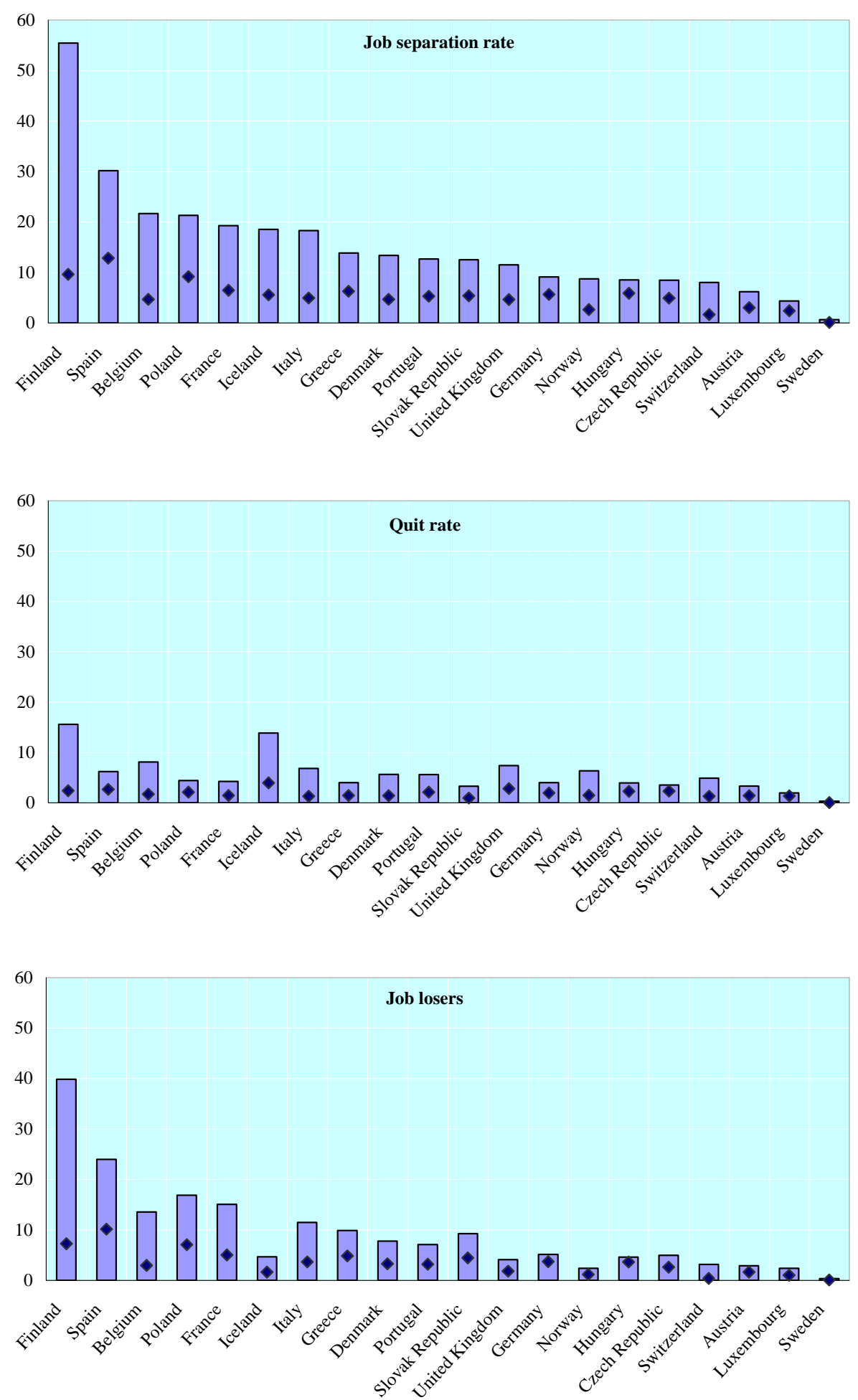

a) The data refer to all persons who are currently not employed but who had been working in a wage and salary job during the previous 12 months. Job losers refer to workers who lost their jobs involuntarily and job quitters to those who left their job voluntarily.

Source: OECD Secretariat calculations based on the European Union Labour Force Survey. 

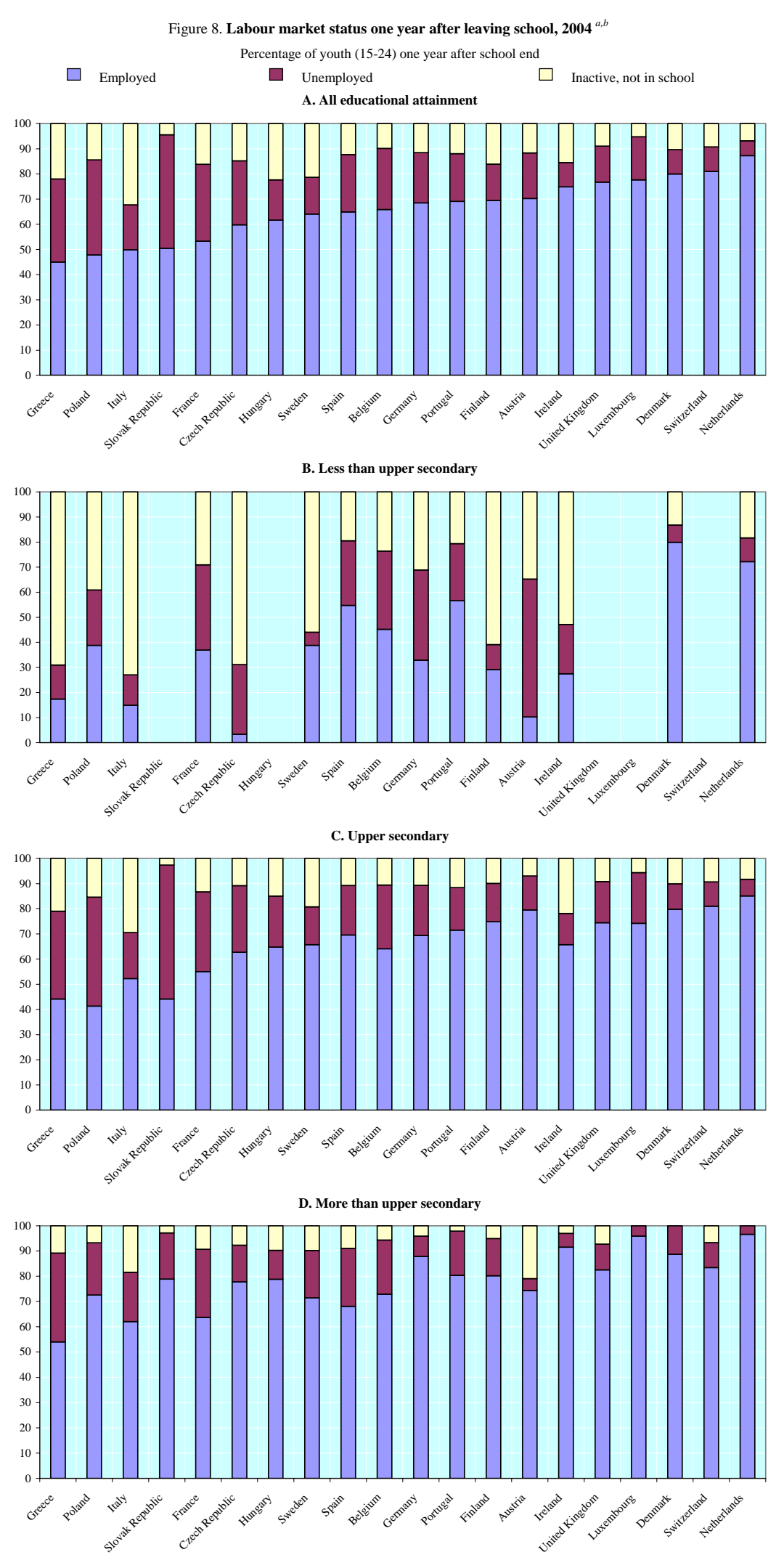

a) 2003 for the Czech Republic, Switzerland and the United Kingdom.

b) Countries are ranked by ascending employment rates for all educational attainment.
Source: OECD Secretariat calculations based on the European Union Labour Force Survey. 
Table 1. Average duration of the transition from school to work in Europe, 1994-2000 ${ }^{a, b}$

Duration in months

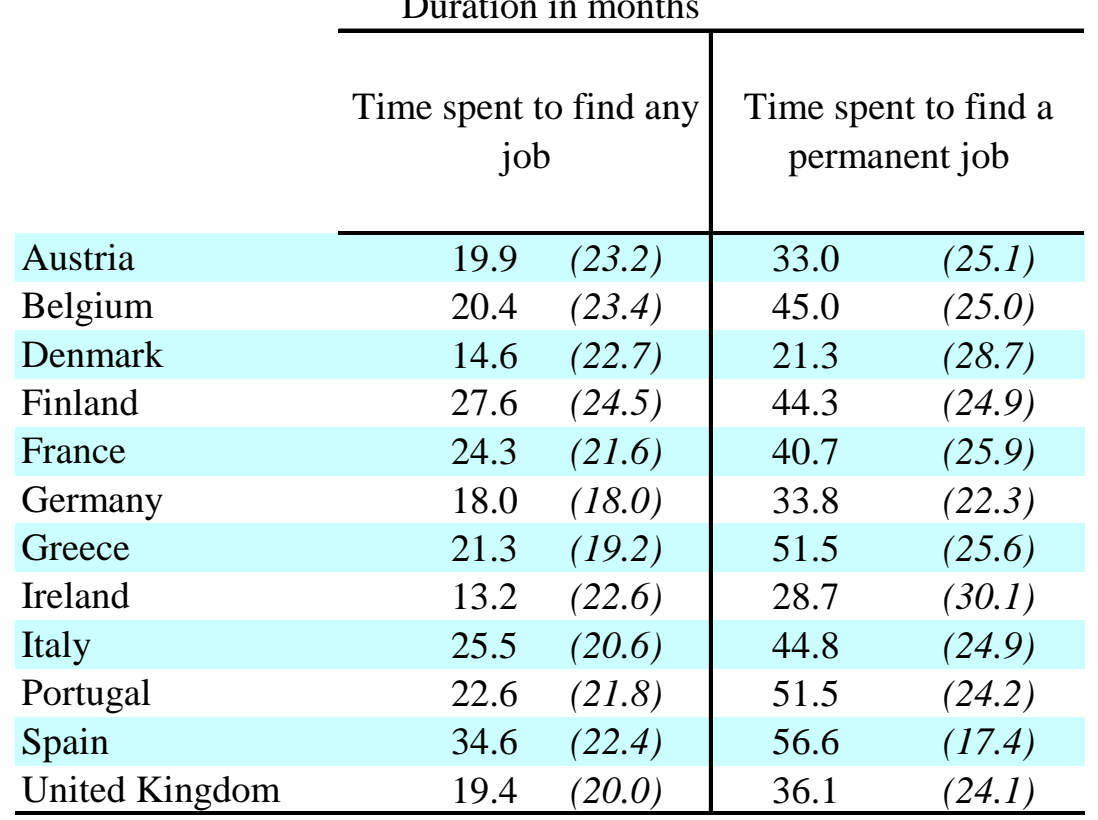

Values within parenthesis are the standard deviations of the estimates.

a) 1995-2000 for Finland.

b) "Short jobs", i.e., those with 15 hours or less per week, are excluded from the calculations.

Source: OECD estimates based on the European Community Household Panel (waves 2 to wave 8 ). 
Figure 9. Share of persons aged 15-29 by activity status in Europe, 2002

Percentages
In education $\square$ Not in education and employed on a temporary basis
$\square$ Not in education and employed (self-employed, family workers etc.) $\quad \square$ Not in education and not employed

Austria

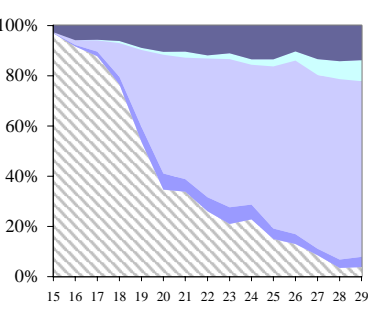

Finland

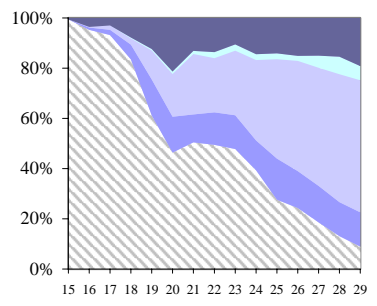

Hungary

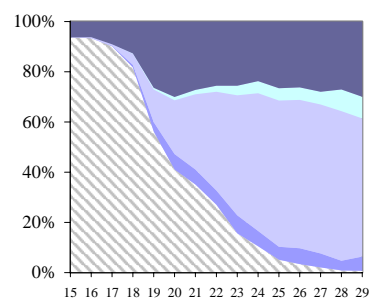

Netherlands

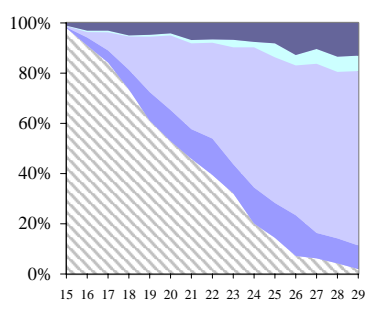

Spain

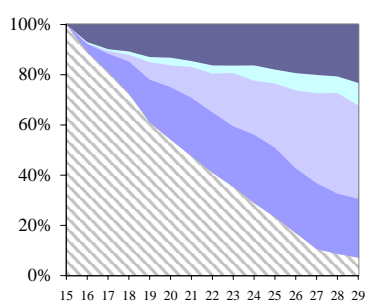

Belgium

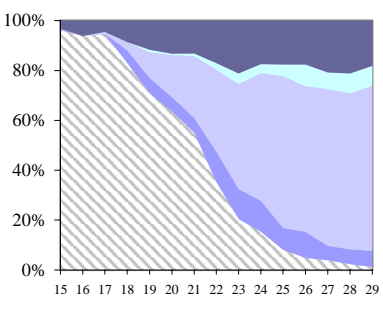

France

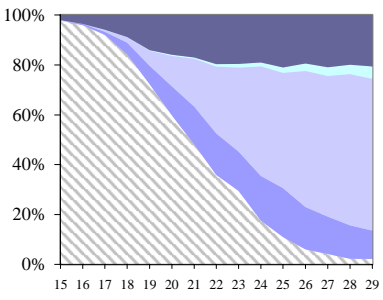

Ireland

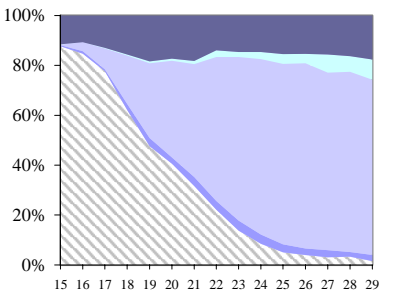

Poland

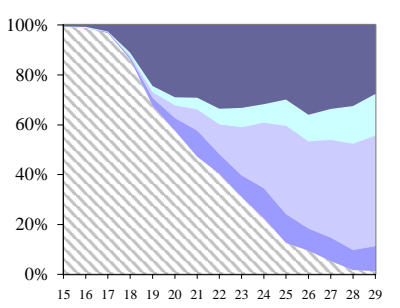

Sweden

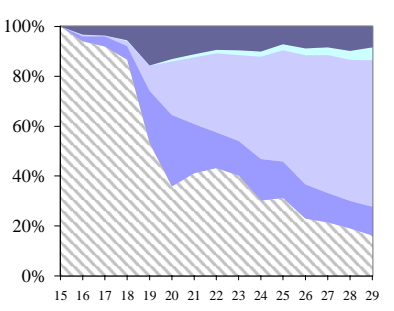

Czech Republic

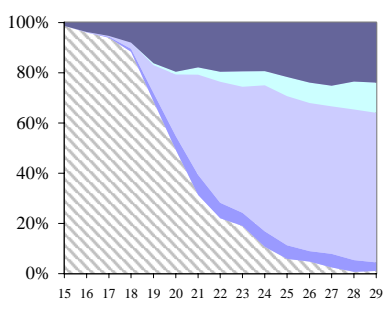

Germany

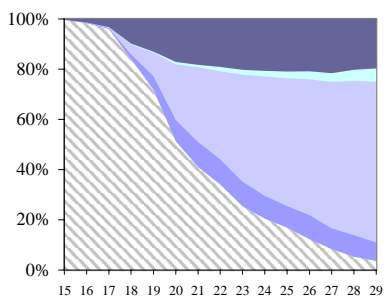

Italy

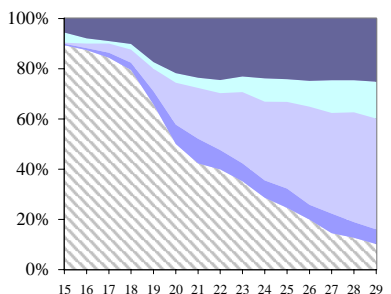

Portugal

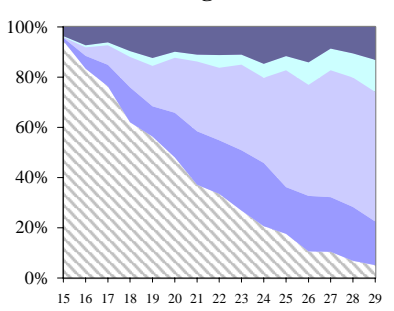

Switzerland

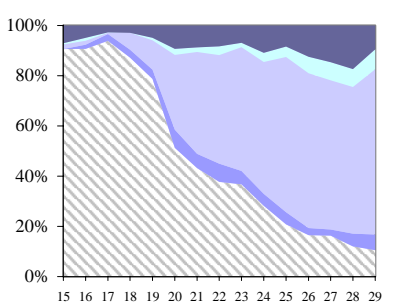

Denmark

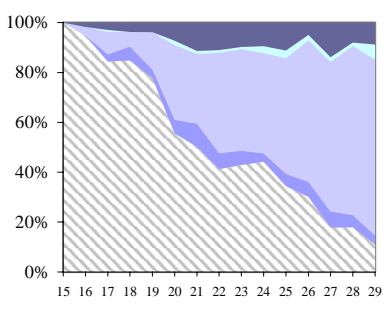

Greece

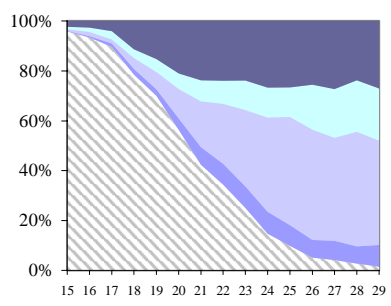

Luxembourg

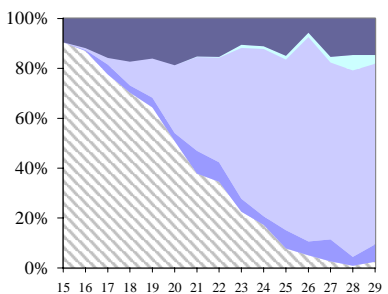

Slovak Republic

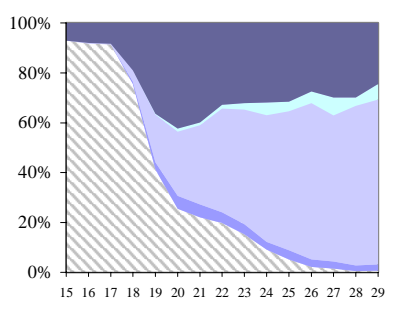

United Kingdom

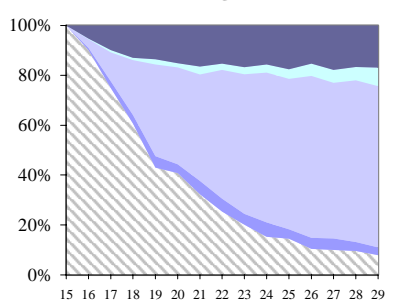

Source: OECD Secretariat calculations based on the European Union Labour Force Survey. 
Table 3. Unemployment experience of youth out-of-school in Europe, 1994-2000 ${ }^{a}$

\begin{tabular}{lc|c|c|c|c}
\cline { 3 - 5 } & $\begin{array}{c}\text { Average number } \\
\text { of unemployment } \\
\text { spells }\end{array}$ & $\begin{array}{c}\text { Average completed } \\
\text { duration in } \\
\text { unemployment } \\
\text { (months) }\end{array}$ & No spell & One spell & $\begin{array}{c}\text { Two or } \\
\text { more } \\
\text { spells }\end{array}$ \\
\cline { 3 - 5 } Austria & 0.8 & 4.9 & 58.5 & 16.8 & 24.7 \\
Belgium & 1.1 & 8.4 & 46.0 & 23.4 & 30.6 \\
Denmark & 1.1 & 5.0 & 37.9 & 48.8 & 13.2 \\
Finland & 1.4 & 9.3 & 33.6 & 28.4 & 38.0 \\
France & 1.5 & 13.3 & 37.1 & 27.9 & 35.0 \\
Germany & 1.0 & 7.1 & 54.5 & 20.6 & 24.8 \\
Greece & 1.2 & 18.7 & 30.2 & 38.0 & 31.9 \\
Ireland & 0.7 & 5.3 & 50.2 & 36.7 & 13.2 \\
Italy & 1.4 & 23.1 & 23.0 & 44.1 & 32.9 \\
Portugal & 1.1 & 9.1 & 40.6 & 28.5 & 30.9 \\
Spain & 2.0 & 22.6 & 17.2 & 25.9 & 56.9 \\
United & 1.0 & 6.4 & 44.4 & 34.0 & 21.6 \\
Kingdom & & & & &
\end{tabular}

a) 1995-2000 for Finland.

Source: OECD estimates based on the European Community Household Panel (waves 2 to wave 8). 
Figure 10. Incidence of temporary work among youths and prime-age adults, $1995^{a}$ and $2005^{b}$

Percentage of dependent employment ${ }^{c}$

$\square \quad 2005 \quad 1995$

Panel A. Youth (15-24)

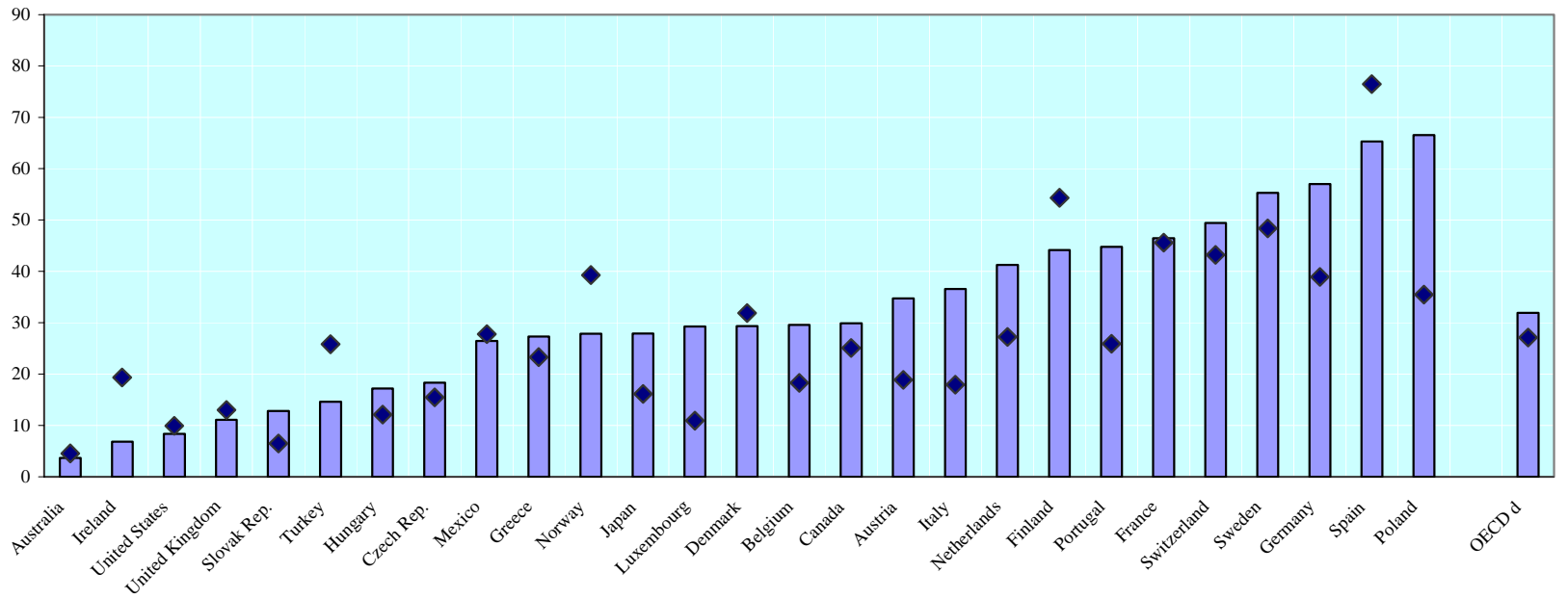

Panel B. Prime-age (25-54)

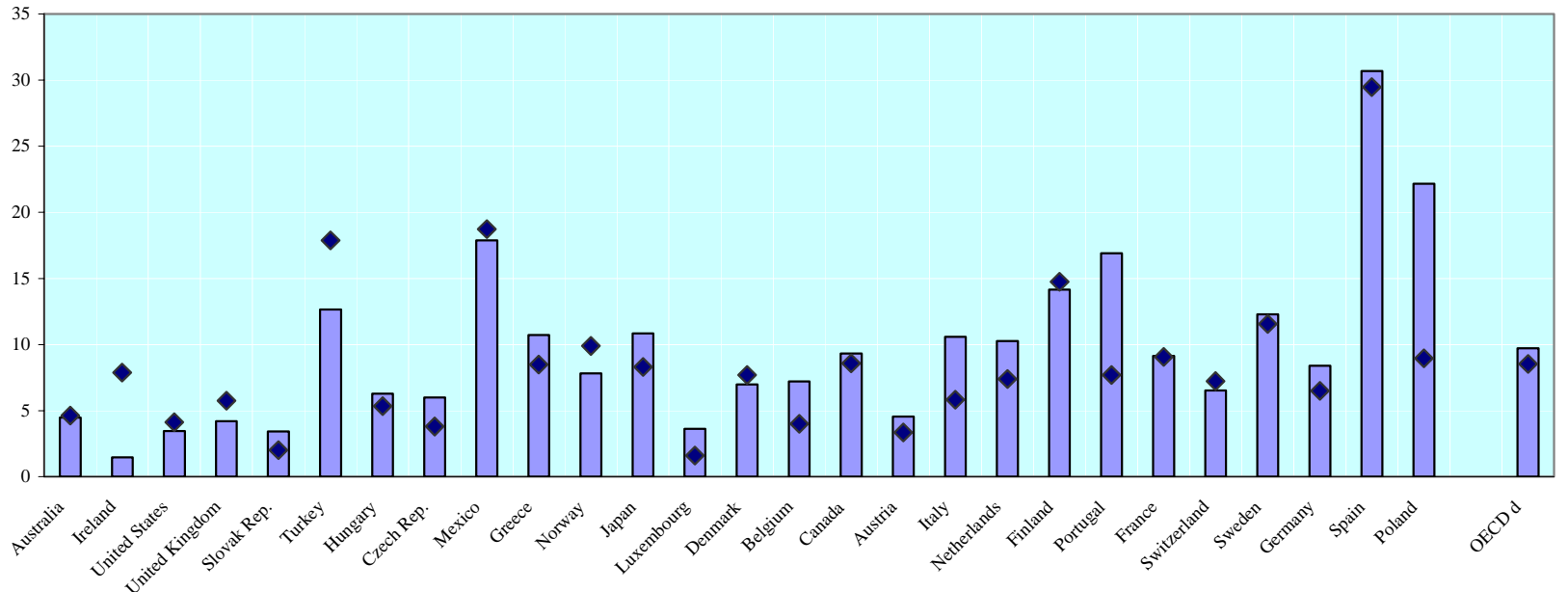

a) 1996 for Luxembourg and Norway; 1997 for Canada, Finland and Hungary; 1998 for Australia; 2001 for Poland.

b) 2004 for Australia and Mexico.

c) Countries shown in ascending order of incidence of temporary employment of youth in 2005 .

d) Unweighted average of countries shown.

Source: OECD database on temporary employment. 
Figure 11. Incidence of temporary work one year after leaving school, $\mathbf{1 9 9 8}^{a}$ and $2004^{b, c}$ Percentage

$\square$ Involuntary temporary work in 2004 Voluntary temporary work in 2004 $\diamond \begin{aligned} & \text { Temporary work } \\ & \text { in } 1998\end{aligned}$

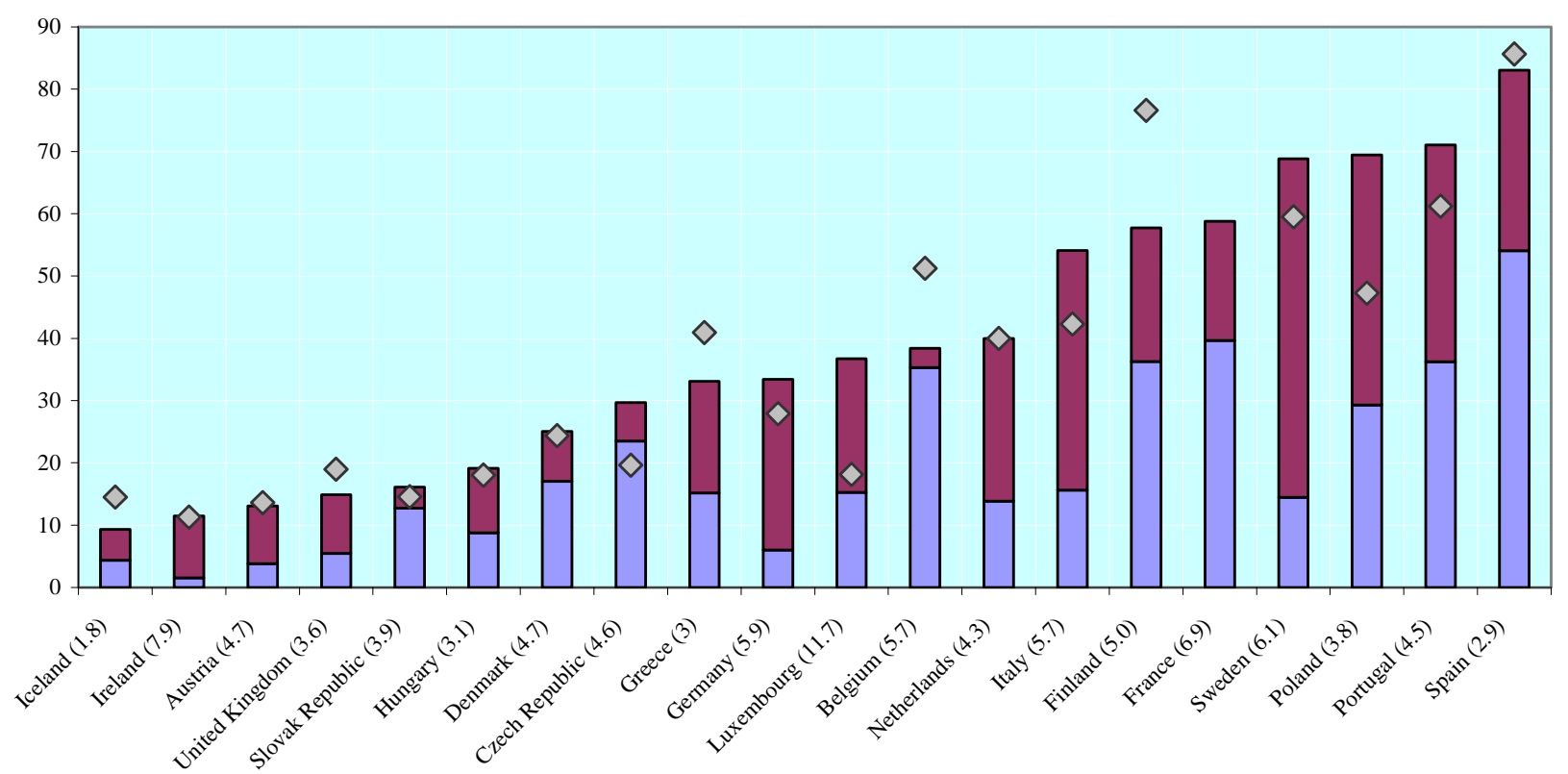

a) 1999 for Belgium, Denmark, Germany, Greece, Luxembourg and Spain; 2000 for Iceland, the Netherlands and Sweden; and 2001 for Poland and the United Kingdom.

b) 2003 for Austria and the Czech Republic.

c) Values within parenthesis are the ratio of the incidence of temporary work of youth (15-24) to that of prime-age adults (25-54) in 2004. Source: OECD Secretariat calculations based on the European Union Labour Force Survey. 
Figure 12. Share of persons aged 18-27 out-of-school in temporary work by age, 1995-2005 Average over the period in percentage
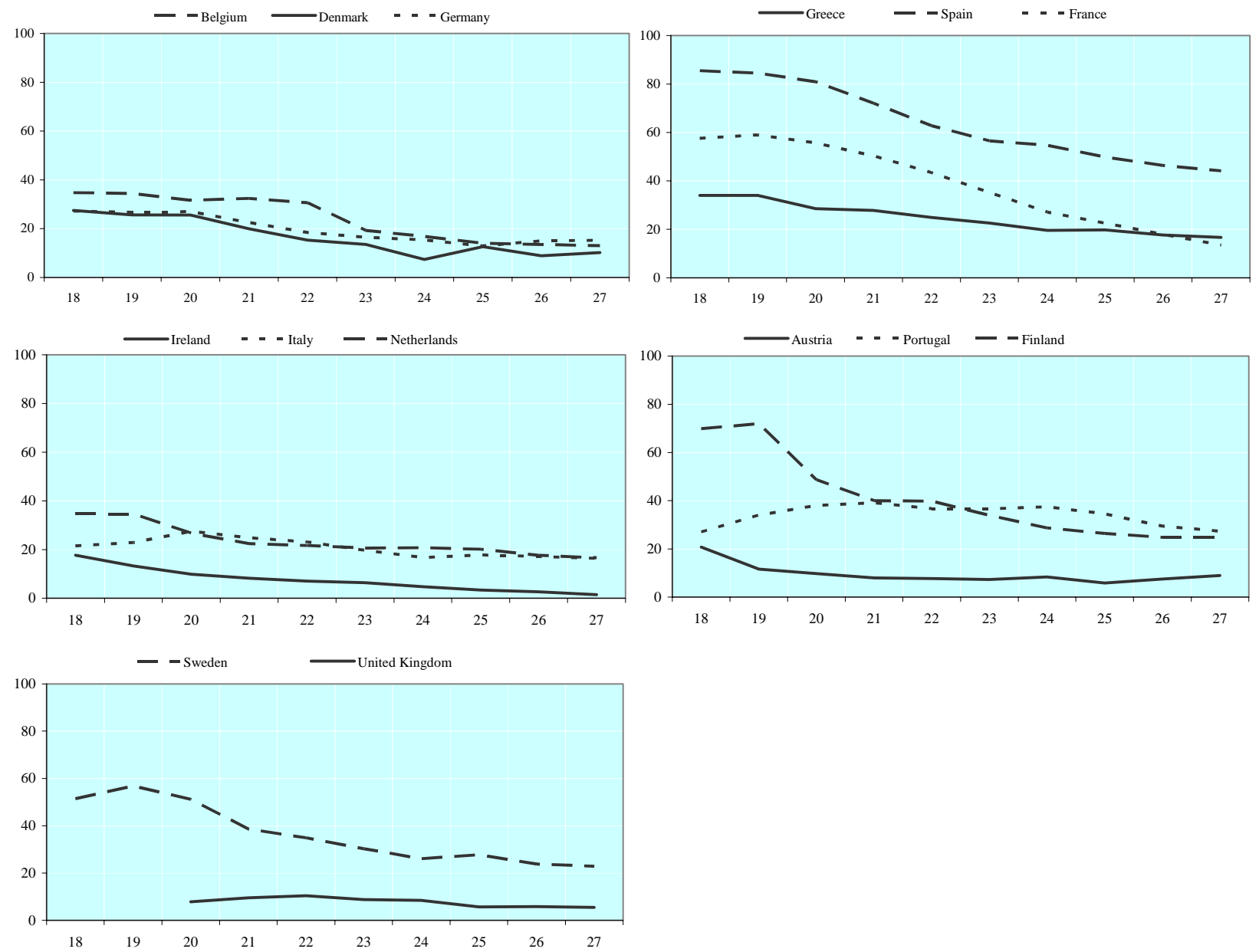

Source: OECD Secretariat calculations based on the European Union Labour Force Survey. 
Figure 13. Transition rates from temporary to permanent work in Europe, 1996 and 2001

Percentage of persons aged 15-28 with a temporary contract in the previous year

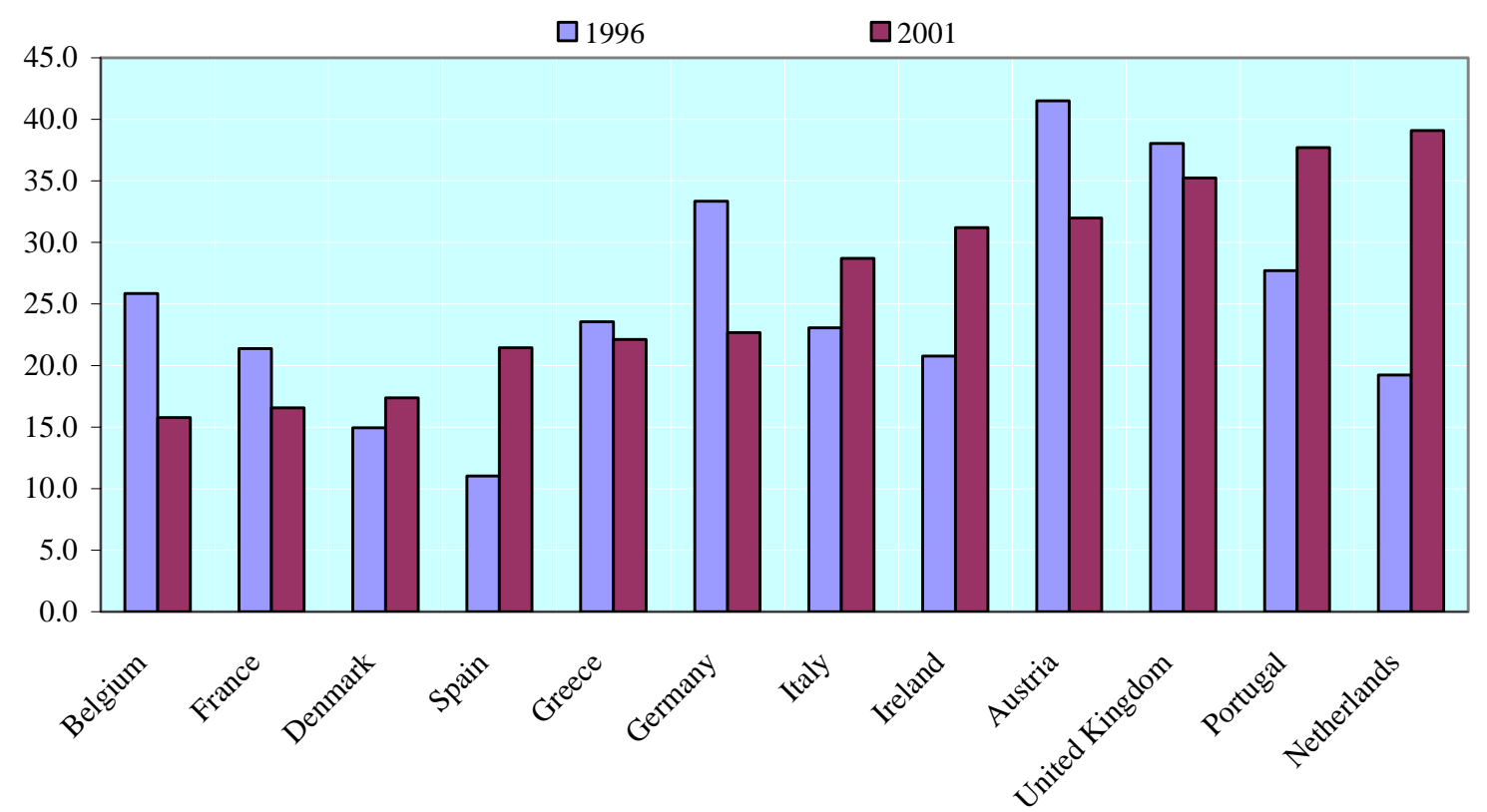

Source: OECD calculations based on the European Community Household Panel (ECHP), waves 2 to 8 (1995-2001). 
Figure 14. Incidence of part-time work one year after leaving school, end of the 1990 's ${ }^{a}$ and $2004{ }^{b}$ Percentage ${ }^{c, d}$

$\diamond$ Incidence of part-time work at the end of 90's

$\square$ Involuntary Part-time job in 2004

$\square$ Voluntary Part-time job in 2004

Panel A. Both sexes
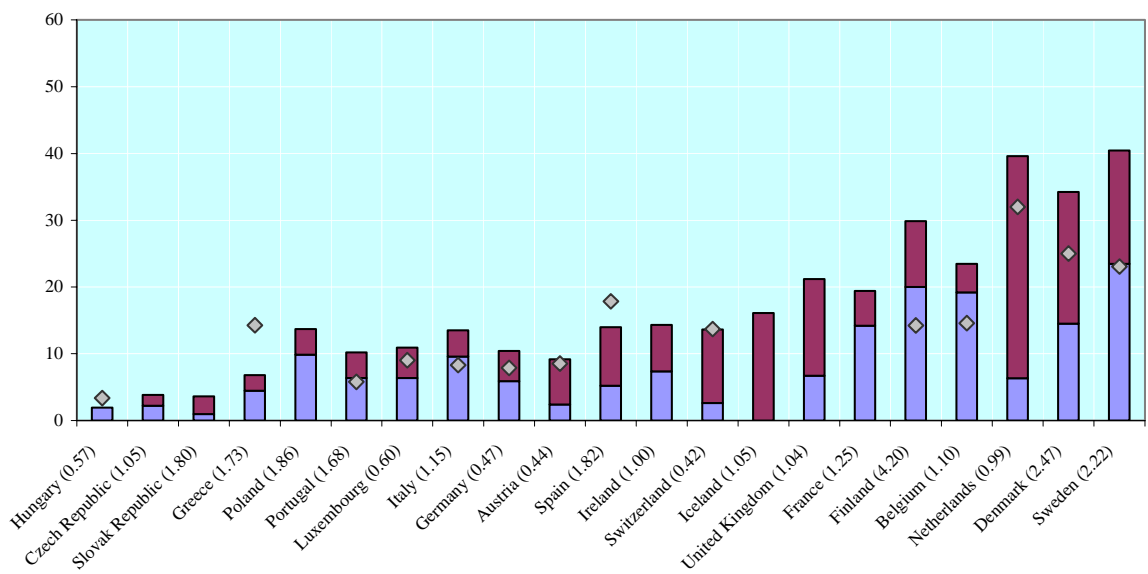

Panel B. Men
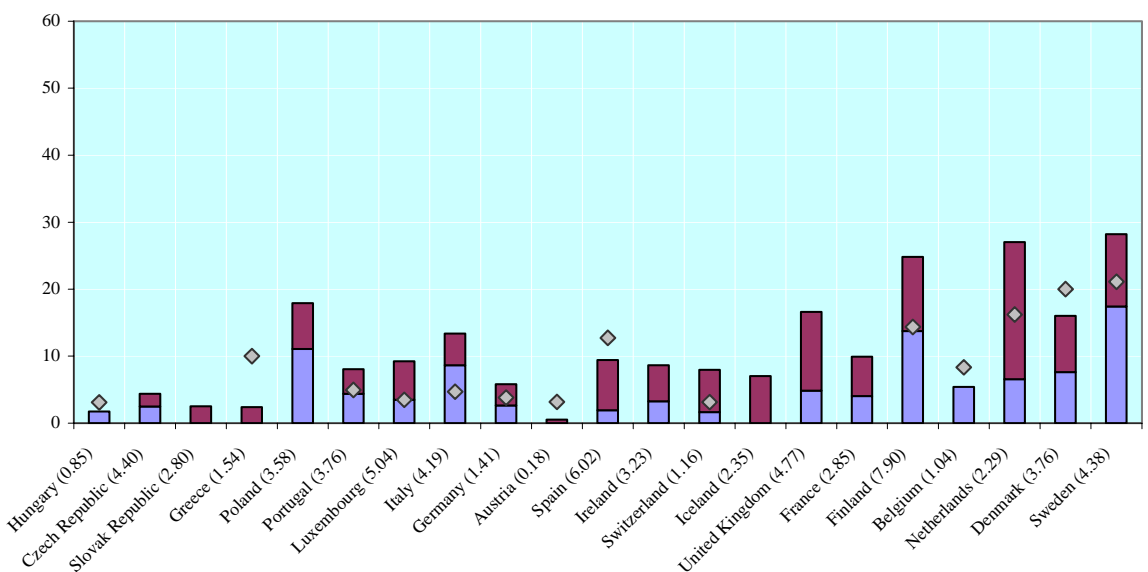

Panel C. Women
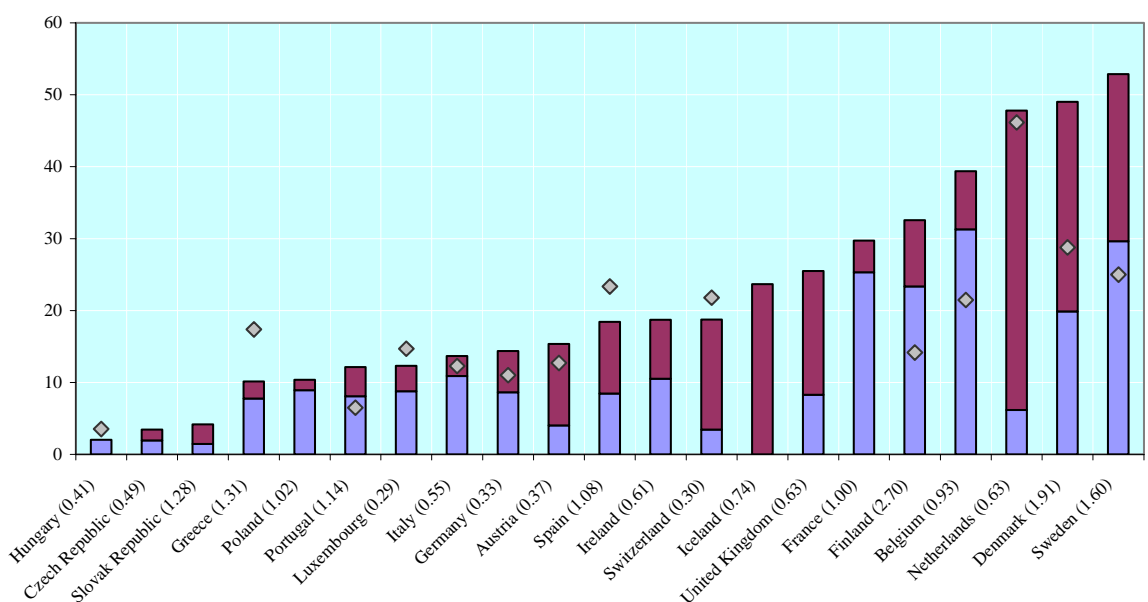

a) 1998 for Finland, Hungary, Italy, Portugal and Switzerland; 1999 for Austria, Belgium, Denmark, Germany, Greece, Luxembourg and Spain; and 2000 for the Nethelats and Swen.

b) 2003 for the Czech Republic and the Slovak Republic.

c) Values within parenthesis are the ratio of the incidence of part-time work of youth to that of adults (25-54) in 2004.

c) Countries are ranked by ascending order of the incidence of part-time job for women in 2004 .

Source: OECD Secretariat calculations based on the European Union Labour Force Survey. 
Figure 15. Alternative measures of low-paid employment ${ }^{a}$ of youth, 15-24, over five years,

$$
\text { 1997-2001 }
$$

Ever low pay

Annual low pay rate

Always low pay

Panel A. Percentage of dependent employees working 15 or more hours per week with low pay ${ }^{c, d}$

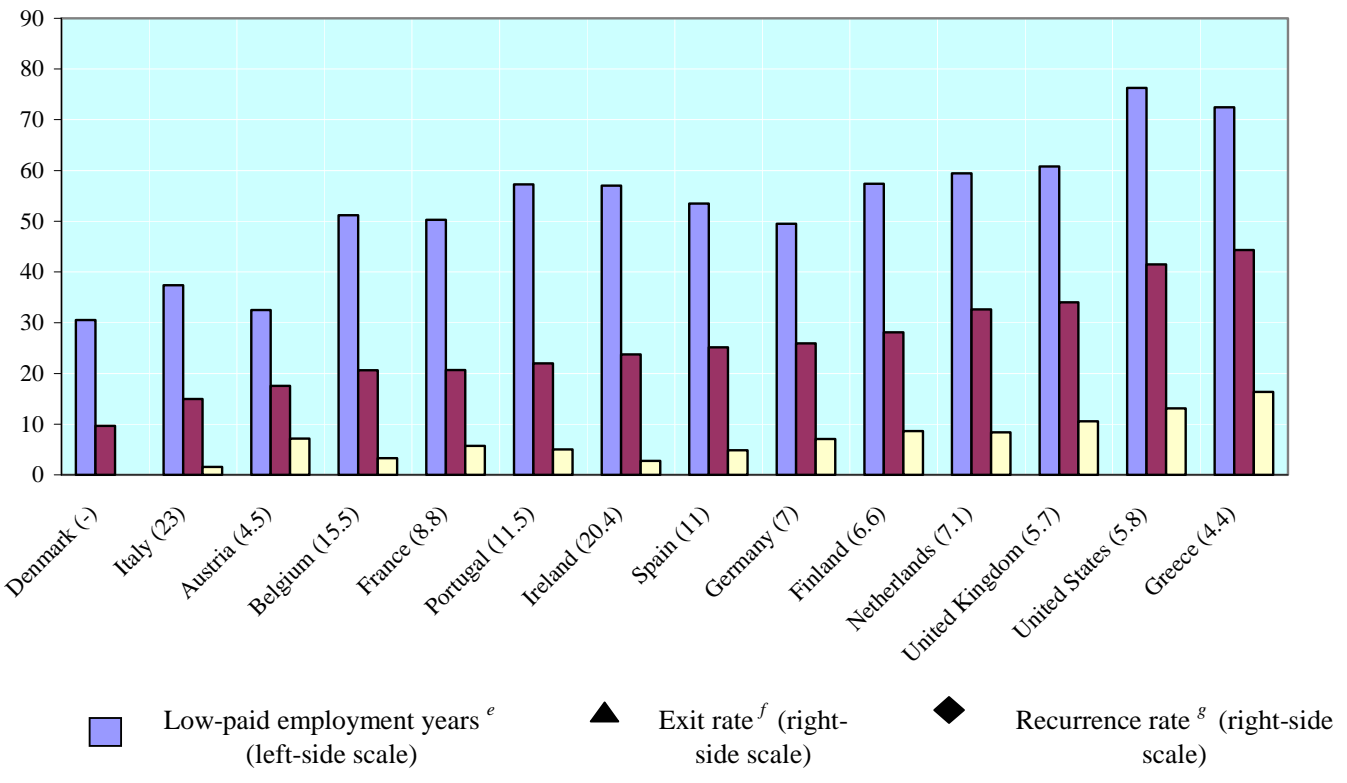

Panel B. Five-year experience of workers who were low paid in the first year and worked at least 15 hours continuously during the five-year period

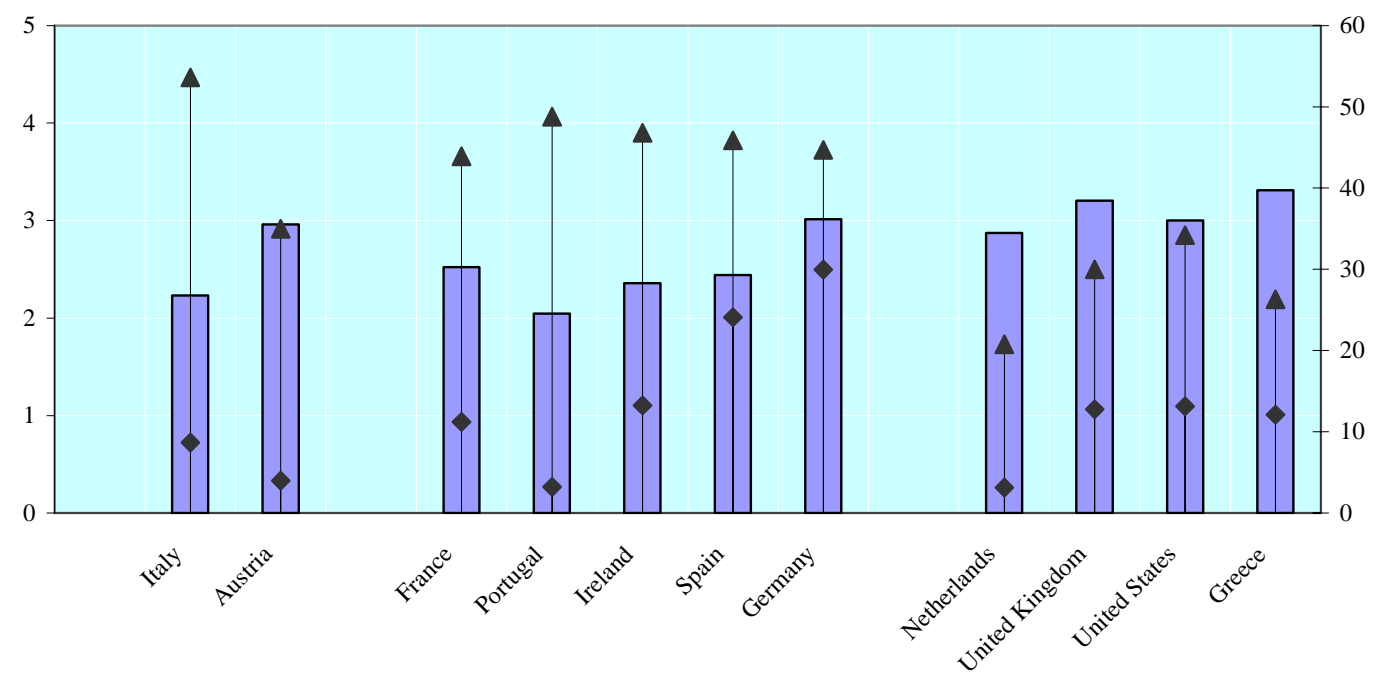

a) Workers are considered to be in low-paid employment if they work at least 15 hours per week and receive an hourly wage of less than two-thirds the median value in that country and year.

b) Countries shown in ascending order of single-year rates of low-paid employment (Panel A).

c) Sample restricted to persons not in education who were continuously employed as dependent employees working at least 15 hours per week during all five years analysed.

d) Values within parenthesis below the country labels in Panel A are the ratio of the ever to the always-low paid (an index of turnover).

e) Average years.

f) Share of 1997 low-paid persons who were high-paid in 1998.

g) Share of 1997 low-paid persons exiting low pay in 1998 but experiencing a repeat spell of low pay during 1999-2001.

Source: OECD Secretariat estimates based on the European Community Household Panel, waves 4 to 8 (1997-2001), for the European countries and based on the Survey of Program Dynamics (SPD) 1997-2001, for the United States. 
Figure 16. Low-pay ${ }^{a}$ incidence in Europe, $\mathbf{1 9 9 5}^{b}$ and 2001

Percentage of persons aged 15-28 working at least 15 hours per week

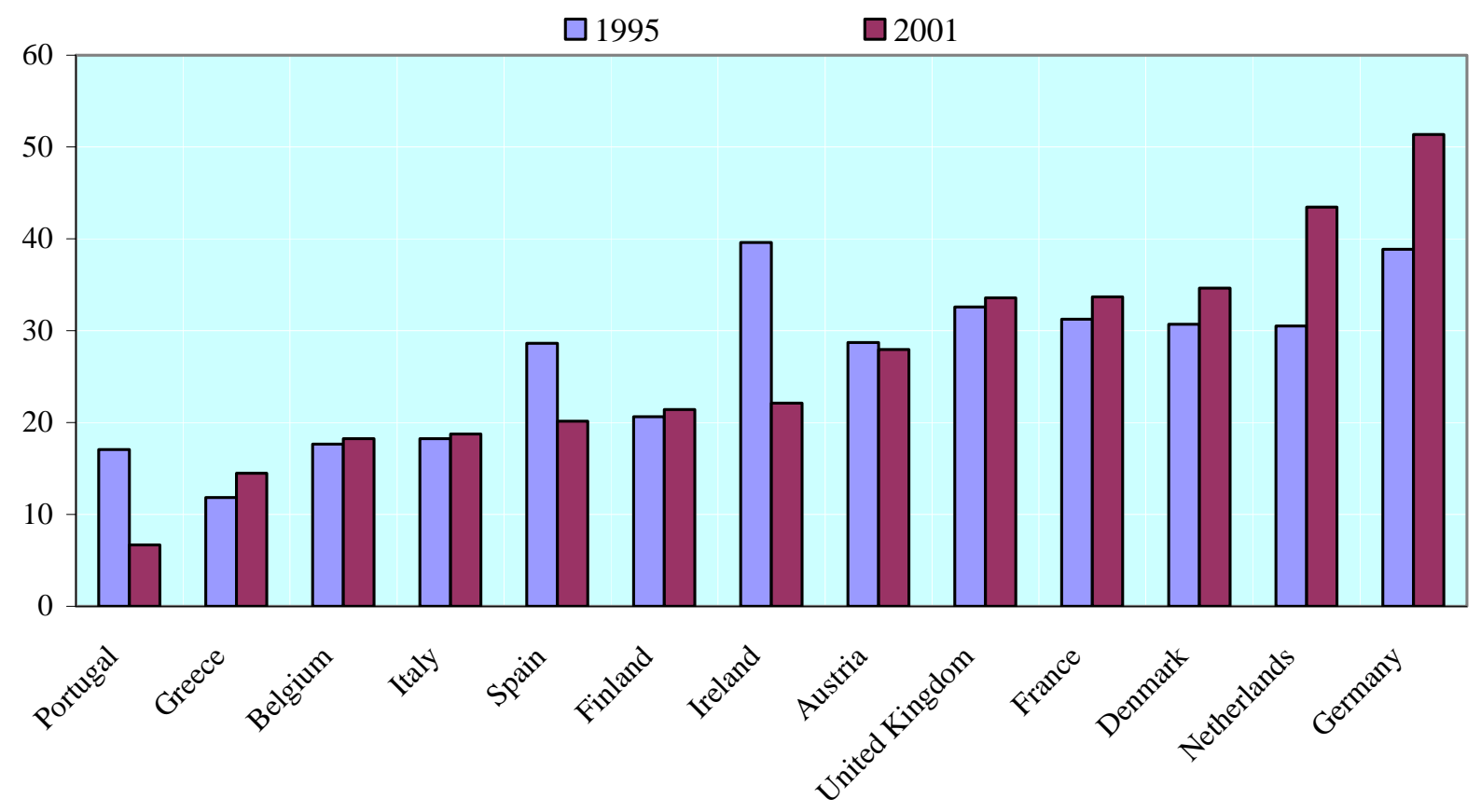

a) Low-paid work corresponds to two third of the gross hourly earnings median of persons aged 25-54.

b) 1996 for Finland.

Source: OECD calculations based on the European Community Household Panel (ECHP), waves 2 to 8 (1995-2001). 
Table 4. Public spending on youth labour market programmes,

1995-2002

\begin{tabular}{|c|c|c|c|c|}
\hline & \multicolumn{2}{|c|}{$\begin{array}{c}\text { As a percentage of } \\
\text { GDP }\end{array}$} & \multicolumn{2}{|c|}{$\begin{array}{c}\text { As a percentage of tota } \\
\text { expenditure in active } \\
\text { labour market } \\
\text { programmes }\end{array}$} \\
\hline & 1995 & 2002 & 1995 & 2002 \\
\hline Australia & 0.06 & 0.08 & 7.5 & 16.9 \\
\hline Austria & 0.01 & 0.02 & 2.3 & 4.7 \\
\hline Belgium & 0.07 & 0.01 & 5.2 & 0.6 \\
\hline Canada & 0.02 & 0.02 & 3.3 & 4.4 \\
\hline Czech Republic & 0.01 & 0.02 & 6.1 & 8.9 \\
\hline Denmark & 0.14 & 0.10 & 7.7 & 6.2 \\
\hline Finland & 0.15 & 0.17 & 9.9 & 17.2 \\
\hline France & 0.27 & 0.40 & 20.8 & 32.2 \\
\hline Germany & 0.06 & 0.10 & 4.2 & 8.6 \\
\hline Ireland & 0.24 & 0.18 & 15.0 & 15.8 \\
\hline Italy & 0.16 & 0.20 & 45.3 & 35.4 \\
\hline Japan & .. & 0.01 & .. & 1.8 \\
\hline Korea & 0.02 & 0.02 & 45.9 & 6.3 \\
\hline Netherlands & 0.10 & 0.04 & 7.0 & 2.4 \\
\hline New Zealand & 0.09 & 0.15 & 12.6 & 28.2 \\
\hline Norway & 0.08 & 0.01 & 6.2 & 1.3 \\
\hline Poland & 0.07 & 0.07 & 18.4 & .. \\
\hline Portugal & 0.33 & 0.22 & 42.3 & 35.6 \\
\hline Slovak Republic & .. & 0.01 & .. & 2.4 \\
\hline Spain & 0.08 & 0.06 & 15.7 & 6.5 \\
\hline Sweden & 0.02 & 0.02 & 0.7 & 1.8 \\
\hline Switzerland & .. & 0.01 & .. & 1.7 \\
\hline United Kingdom & 0.12 & 0.13 & 25.9 & 35.8 \\
\hline United States & 0.03 & 0.02 & 14.8 & 17.2 \\
\hline Unweighted average $^{b}$ & 0.10 & 0.10 & 15.1 & 14.3 \\
\hline
\end{tabular}

a) For Denmark and Portugal, data refer to 2000 instead of 2002; for Ireland data refer to 2001 instead of 2002; for Italy, data refer to 1996 instead of 1995.

b) Average excluding Japan, the Slovak Republic and Switzerland.

Source: OECD database on Labour Market Programmes. 